\title{
Chimery z udziałem pluripotentnych komórek macierzystych jako narzędzie w badaniach biomedycznych
}

\section{STRESZCZENIE}

$\mathrm{T}$ ermin "CHIMERA" znany jest z mitologii greckiej, gdzie określano nim ziejącego ogniem potwora z głową lwa, tułowiem kozy i ogonem węża. Pojęcie to nieobce jest również naukowcom, gdyż we współczesnej biotechnologii znalazło ono zastosowanie dla określenia organizmów zbudowanych z komórek pochodzących od co najmniej dwóch zygot i w związku z tym, różniących się pod względem genetycznym. Chimery tworzone w laboratorium stały się niezwykle cennym narzędziem w badaniach biomedycznych, wykorzystywanym m.in. do doświadczeń nad potencjałem rozwojowym komórek, procesami różnicowania zachodzącymi podczas embriogenezy, a także do analizowania funkcji genów, modelowania ludzkich chorób i opracowywania nowych terapii. Chimery międzygatunkowe dają również nadzieję na wykorzystanie ich do wytwarzania ludzkich narządów do przeszczepów oraz ratowania zagrożonych gatunków. Niniejszy artykuł przedstawia bieżący stan wiedzy na temat chimer tworzonych z udziałem pluripotentnych komórek o charakterze macierzystym, a także perspektywy i zagrożenia związane $\mathrm{z}$ ich wykorzystaniem $\mathrm{w}$ badaniach podstawowych i medycynie.

\section{WPROWADZENIE: CZYM SĄ CHIMERY?}

W prawidłowym rozwoju jednokomórkowy zarodek, czyli zygota, dzieli się na coraz mniejsze komórki i wszystkie one, stopniowo różnicując się, uczestniczą w wykształceniu tkanek powstającego płodu, z którego ostatecznie rozwinie się dorosły osobnik. Okazuje się jednak, że dzięki niezwykłym zdolnościom regulacyjnym w okresie przedimplantacyjnym, zarodek ssaka może rozwijać się prawidłowo nawet w obliczu takich rozwojowych perturbacji, jak niedobór czy nadmiar komórek [1]. Pionierskie doświadczenia profesora Tarkowskiego, wybitnego polskiego embriologa, pokazały, że po eksperymentalnym zespoleniu ze sobą dwóch mysich 8-komórkowych zarodków pozbawionych osłonki przejrzystej, komórki integrują się ze sobą, tworząc jeden zarodek rozwijający się do stadium blastocysty. W tym stadium rozwojowym obecne są trzy pierwsze linie komórkowe: epiblast (EPI, ang. Epiblast), z którego w dalszym rozwoju powstanie ciało zarodka, oraz pierwotna endoderma (PE, ang. Primitive Endoderm) i trofektoderma (TE, ang. Trophectoderm), wchodzące w skład struktur pozazarodkowych podtrzymujących rozwój zarodka w macicy, czyli łożyska i błon płodowych. Doświadczenie Tarkowskiego pokazało, że taka chimerowa blastocysta, po implantacji w drogach rodnych samicy biorczyni, jest w stanie kontynuować rozwój aż do urodzenia prawidłowego fenotypowo, płodnego osobnika o normalnych rozmiarach [2]. W ten sposób, wykorzystując tzw. metodę agregacji zarodków, profesor Tarkowski uzyskał pierwszą mysz - chimerę, zbudowaną z dwóch, odmiennych genetycznie populacji komórek pochodzących od różnych zygot. Podobny, udany eksperyment, zakończony narodzinami mysich chimer, został opisany w pracy autorstwa Beatrice Mintz [3]. Otrzymywane tą metodą chimery zbudowane są z komórek potomnych obu zarodków wyjściowych, a w stadium blastocysty oba komponenty obecne są we wszystkich trzech liniach komórkowych.

Te przełomowe odkrycia utorowały drogę licznym modyfikacjom oryginalnej procedury, co zaowocowało uzyskaniem chimer nie tylko na drodze połączenia dwóch (lub więcej) zarodków w tym samym stadium [4], ale również poprzez agregację normalnego zarodka z zarodkiem w innym stadium rozwojowym [5], z zarodkiem partenogenetycznym [6,7] czy z zarodkami poliploidalnymi [8,9]. Wykazano ponadto, że w celu uzyskania chimer można agregować ze sobą także pojedyncze blastomery [10], węzły zarodkowe (ICM, ang. Inner Cell Mass) pochodzące z blastocyst [11], jak również bruzdkujące zarodki z węzłami zarodkowymi [12]. Dodatkowo, chimery można uzyskać również dzięki kombinacji przedimplantacyjnych zarodków z hodowanymi in vitro pluripotentnymi komórkami o charakterze macierzystym: zarodkowymi komórkami macierzystymi (komórkami ES, ang. Embryonic Stem Cells) oraz indukowanymi pluripo-

\section{mgr Eliza Winek,}

\section{dr hab. Aneta Suwińska ${ }^{\otimes}$}

Zakład Embriologii, Instytut Biologii Rozwoju i Nauk Biomedycznych, Wydział Biologii, Uniwersytet Warszawski

https://doi.org/10.18388/pb.2021_414

$\bowtie$ autor korespondujący: asuwinska@biol. uw.edu.pl

Słowa kluczowe: chimera, komórki pluripotentne, zarodek, komplementacja blastocysty, transplantologia, etyka

Wykaz skrótów: CRISPR - zgrupowane, regularnie rozmieszczone, krótkie, powtarzające się sekwencje palindromowe (ang. Clustered Regularly Interspaced Short Palindromic Repeats); EPI - epiblast; ICM - węzeł zarodkowy (ang. Inner Cell Mass); komórki ES - zarodkowe komórki macierzyste (ang. Embryonic Stem Cells); komórki iPS - indukowane pluripotentne komórki macierzyste (ang. Induced Pluripotent Stem Cells); PE - pierwotna endoderma (ang. Primitive Endoderm); TE - trofektoderma (ang. Trophectoderm)

Podziękowania: Artykuł powstał podczas realizacji projektu OPUS 17: 2019/33/B/ NZ3/02906 finansowanego ze środków Narodowego Centrum Nauki. Autorki chciałyby gorąco podziękować Pani dr hab. Katarzynie Szczepańskiej za cenne wskazówki i komentarze dotyczące manuskryptu. 
tentnymi komórkami macierzystymi (komórkami iPS, ang. induced Pluripotent Stem Cells).

\section{CHIMERY TWORZONE Z UDZIAEEM KOMÓREK ES I IPS}

\section{KOMÓRKI ES I IPS}

Komórki ES wywodzą się z epiblastu, czyli z tej części węzła zarodkowego blastocysty, z której na dalszych etapach rozwoju wykształci się ciało zarodka, a następnie osobnika. Można je uzyskać hodując całe blastocysty lub wyizolowane $\mathrm{z}$ nich węzły zarodkowe in vitro w ściśle zdefiniowanych warunkach zapobiegających ich różnicowaniu. Po raz pierwszy pluripotentne komórki ES wyizolowali z mysich blastocyst w 1981 roku Evans i Kaufman [13] oraz Martin [14]. Kilkanaście lat później komórki ES otrzymano z zarodków naczelnych: małp Rhesus i Cynomolgus [15,16], a w 1998 roku z zarodków człowieka. Do wyprowadzenia linii ludzkich zarodkowych komórek macierzystych (komórki hES, ang. human Embryonic Stem Cells) wykorzystano blastocysty pochodzące $\mathrm{z}$ procedury sztucznego zapłodnienia [17] lub ludzkie pierwotne komórki płciowe wyizolowane z krezki i listew płciowych 5-9 tygodniowych płodów [18]. Wiele lat później zarodkowe komórki macierzyste udało się wyprowadzić również z zarodków szczura [19-22]. Kolejne lata pokazały, że komórki ES można uzyskać nie tylko z całych blastocyst lub wyizolowanych węzłów zarodkowych, ale także z zarodków w stadium moruli [23], a nawet pojedynczych blastomerów [24,25].
Komórki iPS to również komórki o charakterze macierzystym, ale powstałe na drodze przeprogramowania zróżnicowanych komórek somatycznych [26]. Uzyskanie mysich komórek iPS po raz pierwszy opisali japońscy naukowcy Takahashi i Yamanaka w 2006 roku [27]. Doświadczanie polegało na transfekcji komórek somatycznych (mysich fibroblastów dorosłego osobnika) wirusami kodującymi cztery geny, niezbędne dla zachowania pluripotencji zarówno przez komórki budujące przedimplantacyjny zarodek ssaka, jak i przez komórki ES (Oct4, Sox2, Klf4 oraz c-Myc). Nadekspresja tych 4 genów spowodowała, że fibroblasty zaczęły morfologicznie i funkcjonalnie odzwierciedlać cechy komórek ES. Rok później, zespół pracujący pod kierownictwem Yamanaki, indukując nadekspresję tych samych genów, otrzymał analogiczne komórki z fibroblastów ludzkich [28]. W tym samym roku udało się również uzyskać ludzkie komórki iPS, ale z wykorzystaniem innych czynników reprogramujących: Oct4, Sox2, Nanog i Lin28 [29]. W chwili obecnej, aby zwiększyć bezpieczeństwo uzyskiwanych komórek iPS, coraz częściej odchodzi się od pierwotnie stosowanych do transfekcji wektorów wirusowych integrujących do genomu, takich jak retrowirusy czy lentiwirusy, na rzecz episomalnej, czasowej ekspresji genów pluripotencji lub wykorzystania ich produktów - gotowych białek lub mRNA [26]. W przeciwieństwie do procedury uzyskiwania komórek ES, wyprowadzanie komórek iPS, chociaż skomplikowane, nie budzi kontrowersji natury etycznej, ponieważ nie wymaga uśmiercenia zarodków. Komórki iPS są stosunkowo łatwo dostępne i uniwersalne, gdyż, jak pokazały liczne badania,

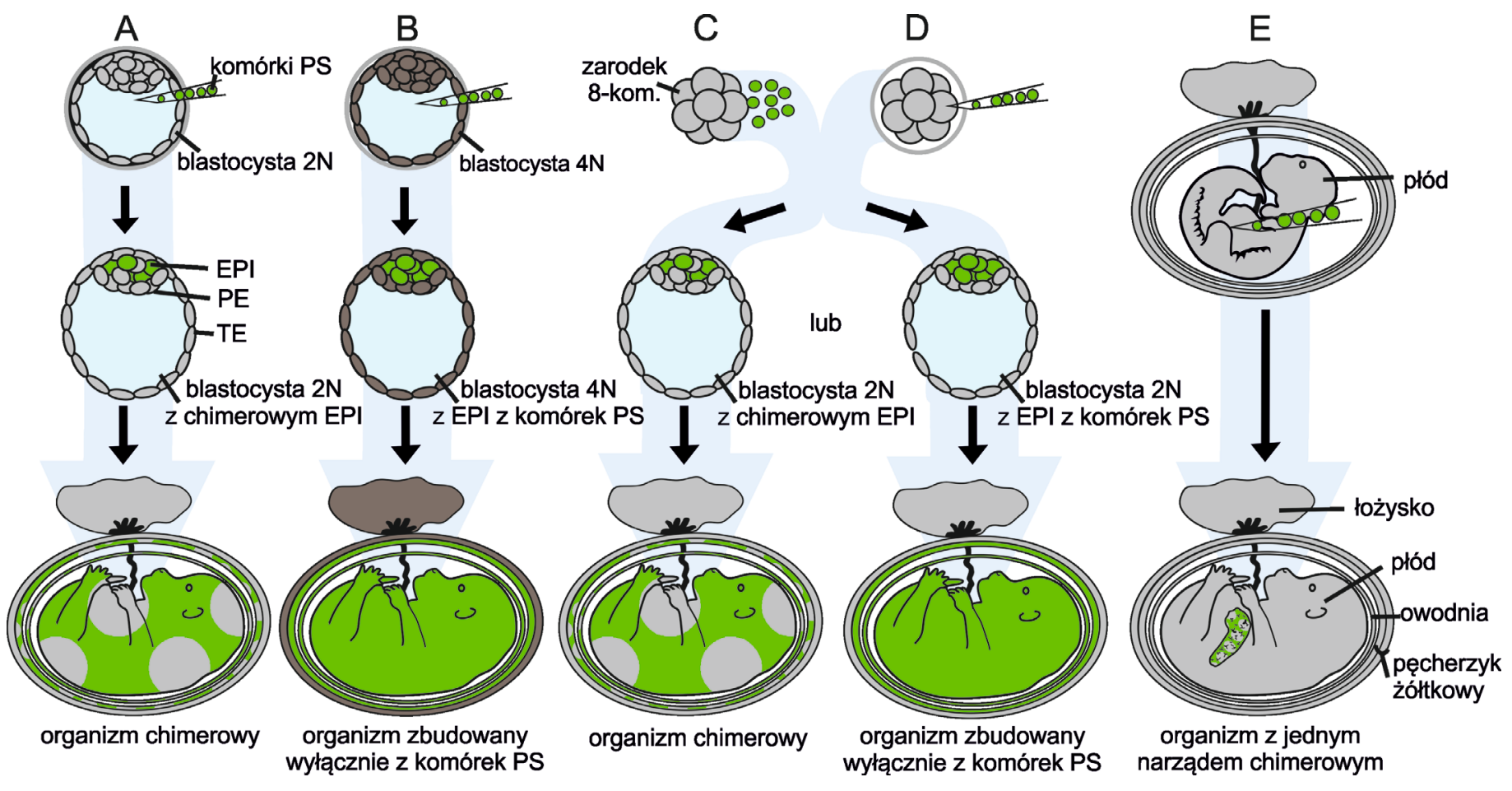

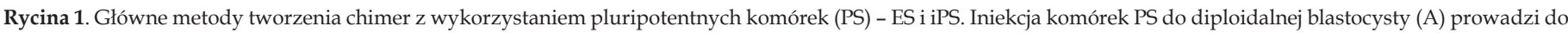

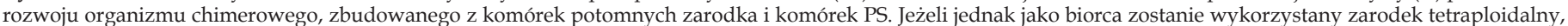

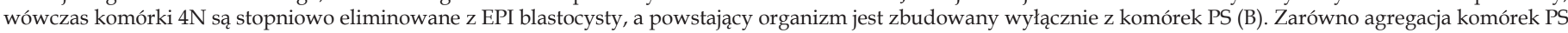

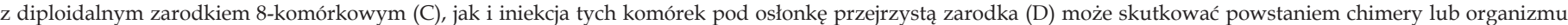

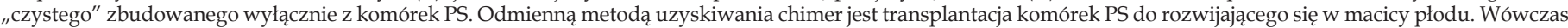
występowanie wprowadzonych komórek może być ograniczone do jednego narządu (E) 
można je uzyskać nie tylko z fibroblastów, ale z wielu innych typów komórek somatycznych.

Pomimo odmiennego pochodzenia, komórki ES i iPS mają wspólne, unikalne właściwości [30]. Po pierwsze, są pluripotentne, co oznacza, że w odpowiednich warunkach hodowli mają zdolność do wielokierunkowego różnicowania we wszystkie typy komórek budujące organizm, włącznie z linią płciową. Po drugie, charakteryzują się zdolnością do samoodnowy swojej populacji z zachowaniem niezróżnicowanego charakteru. Poza tym, eksprymują markery charakterystyczne dla komórek ICM, takie jak Oct4, Nanog czy Sox2 (przegląd w [31]).

Pluripotencję komórek ES i iPS można zweryfikować tworząc chimery. Wykorzystuje się do tego celu klasyczną metodą agregacji albo metodę mikroiniekcji. W tym drugim przypadku komórki pluripotentne wprowadza się przy pomocy mikromanipulatora do wnętrza zarodka diploidalnego $(2 \mathrm{~N})$ albo tetraploidalnego $(4 \mathrm{~N})$, czyli takiego, w którym zestaw chromosomów został podwojony. W przypadku, gdy jako zarodek gospodarza zastosuje się blastocystę diploidalną, komórki ES lub iPS wprowadzone do jej jamy wbudowują się w węzeł zarodkowy i ostatecznie lokalizują wyłącznie w epiblaście [32]. Dlatego po transplantacji utworzonego $\mathrm{w}$ ten sposób chimerowego zarodka do dróg rodnych samicy, linie pozazarodkowe - TE i PE oraz wywodzące się z nich struktury, zbudowane są z komórek blastocysty-biorcy, a urodzone zwierzę jest chimerą, której tkanki stanowią mieszaninę komórek wywodzących się z epiblastu blastocysty oraz potomnych komórek ES lub iPS (Ryc. 1A). Wyjątek stanowi sytuacja, w której komórki ES lub iPS umieszczone zostaną w jamie blastocysty tetraploidalnej, którą można uzyskać w laboratorium dzięki elektrofuzji blastomerów 2-komórkowego zarodka i ich dalszej hodowli. Ponieważ w układzie diploidalno-tetraploidalnym komórki $4 \mathrm{~N}$ zarodka gospodarza ulegają stopniowej eliminacji ze struktur zarodkowych, wchodząc ostatecznie w skład jedynie tkanek pozazarodkowych (łożyska i części błon płodowych), technika ta pozwala na uzyskanie zwierząt wywodzących się całkowicie z komórek potomnych wprowadzonych ES lub iPS, czyli tzw. osobników „czystych” lub osobników „F0” (Ryc. 1B) [33]. Wydajność tej metody, zwanej tetraploidalną komplementacją, jest jednak stosunkowo niska $\mathrm{z}$ uwagi na liczne wady rozwojowe oraz ograniczoną przeżywalność urodzonych osobników [33].

Pewien odsetek osobników „czystych” można uzyskać również poprzez agregację komórek pluripotentnych z zarodkiem 8-komórkowym (Ryc. 1C) lub poprzez iniekcję tych komórek pod osłonkę przejrzystą bruzdkującego, kilkukomórkowego zarodka (Ryc. 1D). W tym przypad$\mathrm{ku}$, po transplantacji do dróg rodnych samicy-biorczyni, może urodzić się albo zwierzę chimerowe albo "czyste”, którego tkanki będą zbudowane wyłącznie z komórek pochodzących od pluripotentnych komórek macierzystych. Uzyskanie zwierzęcia "czystego" jest możliwe dzięki temu, że komórki ES lub iPS wpływają na losy blastomerów, wypierając je z epiblastu (będącego jedyną dostępną niszą dla komórek pluripotentnych) i kierując na alternatywne drogi różnicowania (w PE i TE) [34].
Inny typ chimer powstaje na drodze transplantacji komórek pluripotentnych lub powstających z nich komórek progenitorowych, do płodów w macicy (Ryc. 1E). Choć metoda ta pozwala na ograniczenie występowania wprowadzonych komórek do konkretnej tkanki lub narządu, nie jest powszechnie stosowana ze względu na trudności związane z wykonywaniem manipulacji w macicy i ryzyko uszkodzenia płodu [35].

\section{JAK ROZRÓŻNIĆ KOMÓRKI OBU KOMPONENTÓW W CHIMERZE?}

Kluczowe znaczenie dla określenia stopnia chimeryzmu uzyskanego potomstwa ma identyfikacja i możliwość rozróżnienia komórek potomnych ES lub iPS od komórek potomnych zarodka gospodarza [36]. Dawniej w tym celu powszechnie wykorzystywano różnice w umaszczeniu, które jest charakterystyczne dla danego szczepu myszy. Doświadczenia planowano tak, aby komórki pluripotentne oraz zarodek-biorca miały różne tło genetyczne i pochodziły ze szczepów o odmiennym kolorze sierści. Pomyślna inkorporacja komórek pluripotentnych do rozwijającego się zarodka gospodarza wiązała się wówczas z uzyskaniem chimerowego, "łaciatego" potomstwa. Ponieważ jednak chimeryzm sierści nie odzwierciedla w pełni wkładu komórek pluripotentnych w budowę narządów wewnętrznych, z czasem zaczęto stosować inne znaczniki, takie jak np. markery satelitarne DNA, enzym $\beta$-galaktozydazę kodowany przez bakteryjny gen lacZ, który można było wykryć metodami histochemicznymi, czy elektroforetycznie rozróżnialne warianty pewnych enzymów, specyficznych dla konkretnych szczepów myszy, takie jak np. enzym szlaku glikolizy - izomeraza glukozofosforanowa (GPI, ang. Glucose-6-Phosphate Isomerase) [36]. Obecnie, dzięki rozwojowi inżynierii genetycznej, rolę markerów najczęściej pełnią białka fluorescencyjne. Zastosowanie zarodków oraz linii komórkowych pochodzących od zwierząt transgenicznych, eksprymujących białka reporterowe, takie jak np. białko zielonej fluorescencji (GFP, ang. Green Fluorescent Protein) pozwala na śledzenie losu obu komponentów zarówno w rozwijającym się chimerowym zarodku, jak i po jego urodzeniu oraz umożliwia korelację jego genotypu z fenotypem.

\section{CHIMERY W BADANIU FUNKCJI GENÓW}

Wykazanie możliwości konstruowania chimer z udziałem komórek pluripotentnych i ich prawidłowego rozwoju nie tylko dowiodło ogromnej plastyczności zarodków ssaków, ale otworzyło również drogę do wykorzystania ich jako narzędzia służącego do badań. Jedną z wielu możliwości, jakie z chwilą tego odkrycia otworzyły się przed naukowcami, jest użycie chimer do analizy funkcji genów.

Pod koniec lat 80. ubiegłego wieku dwa niezależne zespoły badawcze kierowane przez Capecchiego i Smithiesa opracowały metodę pozwalającą na precyzyjną modyfikację wybranych genów w komórkach ES [37,38]. Opisana wówczas technika polega na wymianie danego genu na jego zmodyfikowaną wersję na drodze rekombinacji homologicznej. Rodzaj zastosowanej w komórkach ES modyfikacji zależy od informacji, jakie chce uzyskać badacz. Wykorzystując tę metodę możliwa jest zarówno całkowita inaktywa- 
cja wybranego genu (ang. knock-out), jak i zastąpienie istniejącego w komórkach genu jego zmodyfikowaną wersją, np. nieposiadającą sekwencji odpowiedzialnych za powstawanie określonej domeny w białku. Kolejną możliwością jest nadanie komórkom całkowicie nowych właściwości, dzięki wprowadzeniu niewystępującej dotąd w ich genomie sekwencji (ang. knock-in). Potencjalnie każdy gen może zostać zmodyfikowany. W 2004 roku zapoczątkowano projekt występujący pod akronimem KOMP (ang. Knockout Mouse Project), którego celem było otrzymanie i umieszczenie w banku zmodyfikowanych genetycznie linii komórek ES pozbawionych ekspresji każdego z genów występujących u myszy [39]. W ciągu pięciu lat trwania przedsięwzięcia uzyskano linie komórkowe z „,wyłączoną” ekspresją ponad 9000 pojedynczych genów [40]. Po odpowiedniej selekcji, komórki ES zawierające zmodyfikowany gen mogą posłużyć do uzyskania zwierząt chimerowych posiadających określone mutacje (Ryc. 2). Ponadto, jeżeli wprowadzone komórki wejdą w skład linii płciowej, z której wywodzą się gamety, to taki osobnik może przekazać zmodyfikowaną kopię genu kolejnemu pokoleniu. Choć otrzymane potomstwo chimerowego organizmu zawsze posiada tylko jedną zmienioną genetycznie kopię genu, to skrzyżowanie ze sobą dwóch heterozygotycznych osobników umożliwia uzyskanie „czystych”, transgenicznych linii myszy, homozygotycznych pod względem wprowadzonej mutacji. Procedurę tę można przyspieszyć poprzez wprowadzenie homozygotycznych, zmodyfikowanych komórek ES do zarodków tetraploidalnych. Wówczas powstały organizm od razu będzie zbudowany wyłącznie z komórek ze zmienionym genotypem [33].

Możliwość tworzenia transgenicznych zwierząt zapoczątkowała całkowicie nowy rozdział w badaniach funkcji genów. Dzięki rozwojowi technik modyfikacji genetycznej, m.in. opracowaniu technologii CRISPR (ang. Clustered Regularly Interspaced Short Palindromic Repeats)/Cas9 [41] oraz systemu Cre/LoxP [42], obecnie badacz może decydować o miejscu i czasie inaktywacji danego genu. Możliwe jest „wyłączenie" ekspresji wybranego genu nie tylko w danym momencie rozwoju organizmu, ale również w określonej tkance.

Badania mające na celu określenie funkcji wybranego genu najczęściej polegają na inaktywacji jego ekspresji, a następnie analizie fenotypu powstałego organizmu. Interpretacja uzyskanych tą metodą wyników może jednak nastręczać wiele problemów, szczególnie gdy zostanie usunięta sekwencja kodująca genu niezbędna dla funkcjonowania całego organizmu. Dzięki temu, że chimery są wariantem pośrednim między normalnym organizmem a takim zbudowanym wyłącznie ze zmodyfikowanych genetycznie komórek, stanowią one użyteczne narzędzie wykorzystywane do analizy roli genu zarówno w badaniach podstawowych, jak i biomedycznych.

\section{CHIMERY A BADANIA PODSTAWOWE}

Historycznie pierwszym zastosowaniem chimerowych organizmów były badania służące eksperymentalnemu określeniu funkcji genów istotnych w okresie embriogenezy. Zarówno zaburzone formowanie pojedynczej linii komórkowej, jak i wykluczenie zmodyfikowanych komórek z konkretnej tkanki w chimerowym zarodku sugeruje, że ekspresja badanego genu jest niezbędna w danej strukturze $\mathrm{w}$ trakcie normalnego rozwoju. W zależności od tego, czy to wprowadzone komórki ES posiadają zmodyfikowany gen

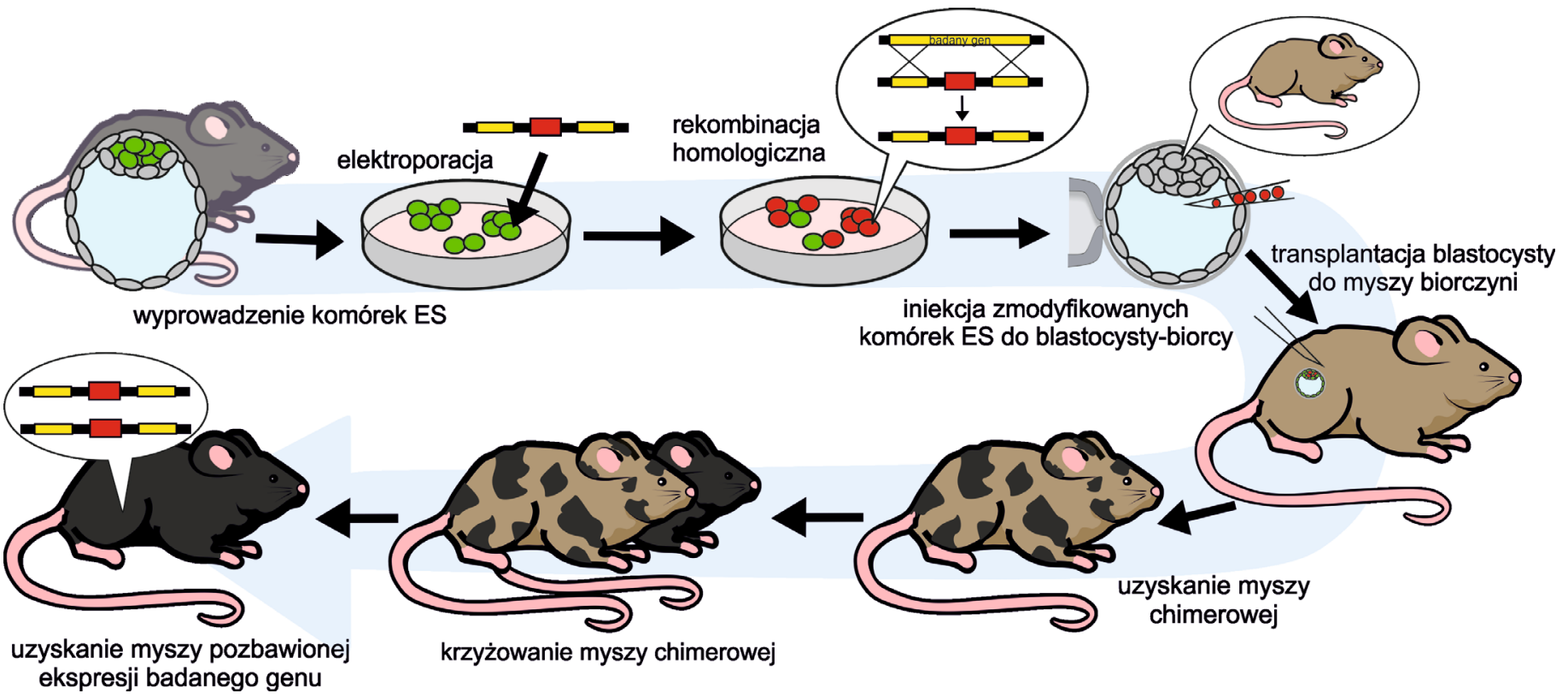

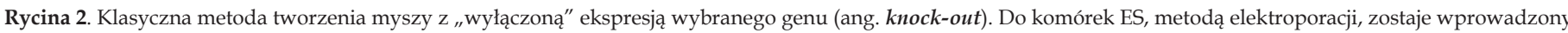

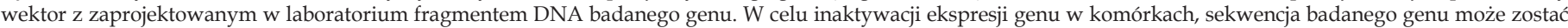

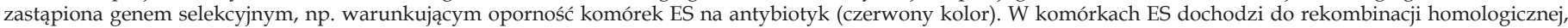

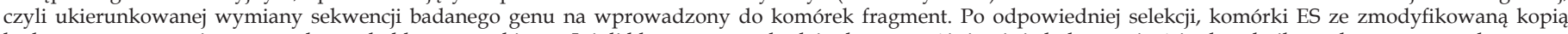

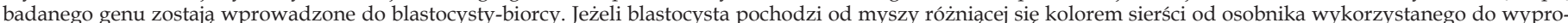

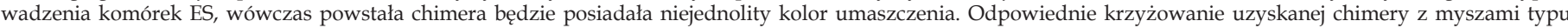

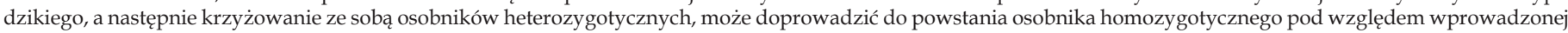
modyfikacji, w którego komórkach badany gen nie będzie eksprymowany. 
czy mutacja obecna jest w zarodku-biorcy, możliwe jest rozstrzygnięcie, czy badany gen bierze udział $\mathrm{w}$ formowaniu tkanek budujących ciało zarodka czy tkanek pozazarodkowych. Wprowadzenie komórek ES pozbawionych ekspresji wybranego genu do prawidłowej blastocysty prowadzi do powstania chimerowego organizmu, w którym mutacja genu ograniczona jest wyłącznie do tkanek zarodka, podczas gdy struktury pozazarodkowe, a więc część błon płodowych i łożysko, są fenotypu dzikiego. Przebieg dalszego rozwoju chimery może mieć dwojaki rezultat, w zależności od miejsca ekspresji badanego genu. Jeżeli podczas niezaburzonej embriogenezy badany gen pełni istotną rolę wyłącznie w tkankach pozazarodkowych, wówczas dalsze etapy rozwoju chimerowego zarodka będą przebiegały prawidłowo. Z kolei, wystąpienie defektów w zarodku może świadczyć o niezbędnej funkcji badanego genu w tkankach organizmu. Do potwierdzenia tej teorii może posłużyć odwrotne podejście badawcze, czyli wprowadzenie komórek ES typu dzikiego do mutantowej blastocysty pozbawionej ekspresji wybranego genu. Wówczas wprowadzone komórki ES typu dzikiego mogą „wyprzeć” zmienione genetycznie komórki z tkanek zarodka, w których ekspresja genu jest niezbędna $\mathrm{w}$ trakcie normalnego rozwoju. W takim przypadku zarodek będzie posiadał prawidłowy fenotyp, nie odróżniający go od zarodków typu dzikiego.

Obserwacje te nie są jednak regułą. W organizmach wielokomórkowych miejsce ekspresji danego genu nie zawsze jest równoznaczne z jego "zapotrzebowaniem”. Działanie genu może być ograniczone do miejsca jego ekspresji, czyli komórkowo-autonomiczne, lub może wpływać na los innych, nie eksprymujących tego genu komórek, co odzwierciedla jego nieautonomiczną funkcję. Analiza zarodków posiadających wyłącznie zmodyfikowane genetycznie komórki często nie jest wystarczająca do rozstrzygnięcia między tymi dwiema funkcjami genu, gdyż nie uwzględnia oddziaływań występujących między komórkami w trakcie normalnego rozwoju. Przewagę pod tym względem mają zarodki chimerowe, które dzięki połączeniu komponentu dzikiego i mutantowego pozwalają na stwierdzenie, czy działanie badanego genu jest ograniczone do pojedynczej komórki, tkanki lub narządu, czy też odgrywa istotną rolę dla formowania sąsiadujących struktur.

W chimerowych zarodkach autonomiczne działanie badanego genu może przejawiać się wypieraniem zmodyfikowanych komórek z konkretnej linii lub tkanki, w której ekspresja tego genu jest niezbędna $\mathrm{w}$ trakcie prawidłowego rozwoju. Dobrze ilustruje to przykład chimerowych zarodków powstałych z połączenia komórek pozbawionych ekspresji genu Klf5 (ang. Krueppel-like factor 5) oraz komórek typu dzikiego [43]. Zarodki, w których inaktywowano oba allele tego genu nie były zdolne do implantacji, przez co ich dalszy rozwój był niemożliwy. Analiza blastocyst chimerowych dowiodła, że tak zmodyfikowane komórki nie wchodzą w skład TE, natomiast lokalizują się specyficznie w ICM [43], co sugeruje autonomiczną rolę genu Klf5 w powstawaniu funkcjonalnej linii TE w rozwoju zarodka myszy.

O komórkowo-autonomicznej funkcji danego genu może także świadczyć zaburzenie funkcji zmodyfikowanych komórek w tkance chimerowego zarodka. Wówczas po- wstały defekt dotyczy wyłącznie komórek o zmienionym genotypie, natomiast nie wpływa na prawidłowe działanie komórek typu dzikiego [44,45]. Taki fenotyp zauważono m.in. podczas badania funkcji genu Dab1 (ang. Disabled-1), którego produkt uczestniczy w ważnych etapach rozwoju kory mózgowej u myszy - migracji oraz pozycjonowaniu neuronów [46]. W chimerowych zarodkach, zbudowanych z komórek pozbawionych ekspresji genu Dab1 oraz komórek typu dzikiego, neurony powstałe ze zmodyfikowanych komórek gromadziły się w jednej płaszczyźnie, tworząc nieprawidłową korę mózgu z odwróconymi warstwami. Natomiast neurony wywodzące się z komórek typu dzikiego formowały prawidłową korę położoną powyżej tej zbudowanej przez neurony Dab1 [46]. Takie przestrzenne i funkcjonalne oddzielenie dwóch komponentów w chimerowych zarodkach stanowi potwierdzenie komórkowo-autonomicznej funkcji genu.

Z kolei nieautonomiczna funkcja oznacza, że efekt działania danego genu występuje w innej komórce, tkance lub narządzie, niż w tych, w których zachodzi jego ekspresja. Stąd wprowadzenie nawet niewielkiej liczby komórek ES typu dzikiego może być wystarczające do przywrócenia prawidłowego fenotypu mutantowego zarodka. W takim przypadku obserwowane "terapeutyczne działanie” komórek ES wynika zapewne z wydzielania przez nie czynników kompensujących brak produkcji określonego białka przez tkankę ze zmodyfikowanym genem $[47,48]$.

Jednym z nowszych przykładów wykorzystania chimerowych zarodków do określenia roli genu są badania $\mathrm{Hu}$ ang i wsp., mające na celu poznanie funkcji czynnika Zfp281 (ang. Zinc Finger Protein 281) w czasie embriogenezy myszy [49]. Nie było to proste zadanie, gdyż zarodki pozbawione obu alleli tego genu wykazywały nieprawidłowości dotyczące zarówno epiblastu, jak i endodermy proksymalnej, czyli tkanki pozazarodkowej wywodzącej się z pierwotnej endodermy. Aby rozstrzygnać między komórkowo-autonomiczną i nieautonomiczną funkcją Zfp281, autorzy wprowadzili komórki ES pozbawione ekspresji tego genu do tetraploidalnych blastocyst, które następnie przeszczepili do samicy biorczyni. Okazało się wówczas, że pomimo, iż ekspresja Zfp281 była nieobecna wyłącznie w EPI, to chimerowe zarodki wykazywały takie same defekty rozwojowe jak homozygotyczne mutanty Zfp281\% [49]. Obserwacje te pozwoliły autorom na stwierdzenie, że gen ten działa autonomicznie w komórkach EPI oraz nieautonomicznie w endodermie proksymalnej w czasie poimplantacyjnego rozwoju myszy. Przykład ten pokazuje zatem, że niektóre geny mogą działać zarówno autonomicznie, pełniąc istotne funkcje w miejscu ekspresji, jak i nieautonomicznie - wpływając na rozwój sąsiadujących tkanek. W takim przypadku, wykorzystanie chimerowych zarodków, posiadających komponent mutantowy i typu dzikiego, stanowi jedną z podstawowych metod badawczych pozwalających na ujawnienie funkcji genu w zależności od rodzaju tkanki.

\section{CHIMERY NA TROPIE SKOMPLIKOWANEGO FENOTYPU}

Obumieranie homozygotycznych mutantów na wczesnych etapach embriogenezy jest jedną z główną przyczyn ograniczających badania funkcji genu w określonych tkan- 
kach i narządach. Obecność komórek typu dzikiego w chimerowych zarodkach może „uratować” letalny fenotyp mutanta, umożliwiając jego dalszy rozwój, a tym samym daje szansę na śledzenie losu zmodyfikowanych genetycznie komórek podczas kolejnych etapów embriogenezy. Wówczas często okazuje się, że dany gen pełni wiele różnych funkcji w zależności od stadium rozwoju organizmu. Wykorzystanie chimerowych zarodków ujawniło na przykład podwójną funkcję genu trombomoduliny w trakcie embriogenezy myszy, najpierw w prawidłowym funkcjonowaniu łożyska, a następnie we właściwym działaniu układu krzepnięcia krwi [50]. Nie jest to jednak odosobniony przypadek. Wykorzystaniu chimer zawdzięczamy poznanie dotąd nieznanych funkcji wielu genów, kluczowych dla wczesnych etapów rozwoju zarodka m.in. Sox2 (ang. Sex Determining Region Y Box Transcription Factor 2) [51], Gata6 (ang. GATA Binding Protein 6) [52] czy PLC- $\gamma 1$ (ang. Phospholipase C- $\gamma 1$ ) [53]. Funkcja tych czynników na dalszych etapach rozwoju była maskowana przez letalność homozygotycznych mutantów na wczesnych etapach rozwoju. Zagadnienie to dobrze ilustruje przykład wykorzystania chimerowych zarodków w badaniach funkcji genu Tfap2a (ang. Transcription Factor AP-2 Alpha). Homozygoty pozbawione obu alleli tego genu wykazywały szereg nieprawidłowości morfologicznych, które prowadziły do śmierci mutantów [54]. Wykorzystanie chimer zbudowanych z komórek Tfap $2 a^{-/}$oraz komórek typu dzikiego nie tylko pokazało, że Tfap $2 a$ niezależnie uczestniczy w powstawaniu wielu struktur, m.in. prawidłowej cewki nerwowej, twarzoczaszki, kończyn oraz ściany ciała zarodka, ale pozwoliło także na odkrycie dotąd nieznanej funkcji tego genu w formowaniu oczu na dalszym etapie mysiej embriogenezy.

Letalność zarodków pozbawionych ekspresji wybranego genu na wczesnych etapach embriogenezy, nie jest jedyną przeszkodą stającą na drodze badacza. Defekty występujące w homozygotach często dotyczą wielu różnych tkanek, co utrudnia odróżnienie wad wynikających bezpośrednio z mutacji genu, od takich, które powstały wtórnie na skutek zaburzeń w funkcjonowaniu organizmu. Wykorzystanie chimerowych zarodków może być pomocne i w tym aspekcie, a uzyskane wyniki mogą dostarczyć nowych informacji o danym genie. Na przykład badania z wykorzystaniem chimerowych zarodków zbudowanych z komórek ES pozbawionych genu Smad1 (ang. SMAD family member 1) [55] czy mysiego homologu genu Hdh (ang. Huntington's disease gene homolog) [56], oraz komórek tetraploidalnych udowodniły, że obserwowane w mutantach anomalie są wtórnym defektem wynikającym z zaburzeń w formowaniu tkanek pozazarodkowych. W powstałych chimerach "zastąpienie" tkanek o zmienionym genotypie tymi wywodzącymi się z komórek tetraploidalnych umożliwiło dalszy rozwój mysich zarodków.

\section{CHIMERY MIĘDZYGATUNKOWE}

Od czasu pionierskich doświadczeń Nicole Le Douarin, która stworzyła chimery dwóch gatunków ptaków - kury i przepiórki, naukowcy podejmowali liczne próby aby pokonać barierę międzygatunkową i stworzyć chimery złożone z zarodków należących do dwóch różnych gatunków ssaków. Żywe, dorosłe chimery międzygatunkowe udało się uzyskać w przypadku blisko spokrewnionych, ale nie krzyżujących się ze sobą gatunków myszy - Mus musculus i Mus caroli, dwóch gatunków bydła - Bos taurus i Bos indicus, a także owcy i kozy Ovis aries i Capra hircus [57]. Szacuje się, że owca i koza są odległe od siebie ewolucyjnie o około 10 milionów lat (http://www.timetree.org), a dystans genetyczny pomiędzy tymi gatunkami wynosi ok. 3\%.

Chimery gatunków ssaków taksonomicznie bardziej odległych od siebie zwykle nie rozwijają się tak pomyślnie. $\mathrm{Z}$ nielicznych przykładów opisanych w literaturze można wymienić np. chimery mysz - szczur [58], pomiędzy którymi dystans ewolucyjny szacowany jest na około $20 \mathrm{mi}-$ lionów lat (http:/ / www.timetree.org). Wydajność tworzenia takich chimer metodą agregacyjną jest niewielka, a te, które przeżywają, wykazują szereg anomalii rozwojowych. Może być to spowodowane niezgodnością komórek trofoblastycznych zarodka jednego gatunku z tkankami macicy innego gatunku. Problem ten nie istnieje w przypadku chimer powstałych w wyniku wprowadzania komórek pluripotentnych jednego gatunku do blastocysty innego gatun$\mathrm{ku}$, a następnie jej transplantacji do biorczyni należącej do tego samego gatunku co blastocysta. Ponieważ komórki ES i iPS kolonizują w chimerach wyłącznie epiblast, system ten pozwala na tworzenie zarodka $\mathrm{z}$ chimerowym węzłem zarodkowym, który jest otoczony przez trofektodermę zgodną gatunkowo z tkankami macicy biorczyni. Pomyślny rozwój chimer tworzonych z udziałem komórek ES opisano po raz pierwszy w przypadku myszy domowej Mus musculus i myszy zaroślowej Apodemus sylvaticus, których różnica w genomie wynosi aż 18\% [59]. Zwierzęta powstałe na drodze mikroiniekcji komórek ES Apodemus sylvaticus do blastocysty Mus musculus wykazywały fenotyp będący mieszanką cech obu gatunków: charakteryzowały się m.in. pośrednim rozmiarem oczu oraz skocznością. Komórki dawcy w powstałej chimerze zasiedlały różne tkanki (w niektórych ich udział sięgał nawet 40\%), łącznie z linią płciową [59].

\section{CHIMERY MIĘDZYGATUNKOWE: JAK LEPIEJ ZROZUMIEĆ ROZWÓJ LUDZKIEGO ZARODKA}

Modelowym gatunkiem, służącym do eksperymentalnych badań nad rozwojem zarodka ssaków, w tym człowieka, jest mysz. Coraz więcej dowodów wskazuje jednak na to, że istnieją znaczące różnice w programach rozwojowych tych dwóch gatunków ssaków, dotyczące m.in. morfologii epiblastu, formowania tkanek pozazarodkowych czy tempa różnicowania [60]. Z tego względu poszukuje się nowych modeli do badania różnych aspektów wczesnego okresu rozwojowego człowieka. Ostatnia dekada przyniosła ogromny postęp w badaniach ludzkiego rozwoju zarówno bezpośrednio, poprzez obserwację $\mathrm{w}$ hodowli in vitro ludzkich zarodków pozyskanych od pacjentów klinik leczenia niepłodności [61,62], jak również przy pomocy tzw. embrioidów, czyli modeli embrionów stworzonych z komórek macierzystych $[63,64]$. Oba te podejścia stanowią dla naukowców duże wyzwanie, gdyż wiążą się z nimi liczne obostrzenia prawne $i$ etyczne. $W$ wielu krajach do niedawna przyjmowało się, że badania na ludzkich zarodkach można prowadzić tylko do 14. dnia po zapłodnieniu, czyli do okresu, w którym wykształca się oś przyszłego płodu i formują się listki zarodkowe, z których powstanie jego ciało. W maju 2021 roku Międzynarodowe Towarzystwo Badań 
nad Komórkami Macierzystymi (ISSCR, ang. International Society for Stem Cell Research) zniosło tę górną granicę, pozostawiając decyzję o długości trwania takich eksperymentów w gestii komisji bioetycznych, co tylko wzmogło związane z nimi zastrzeżenia natury etycznej.

Inna strategia zakłada badanie ludzkich komórek ES lub iPS czy tworzonych z ich udziałem organoidów w hodowli in vitro. Jednakże, ze względu na złożoność procesów rozwojowych oraz interakcje komórek zarodka z komórkami układu nerwowego, krwionośnego, immunologicznego i hormonalnego, nie można rozwoju zarodka ludzkiego, w tym architektury i fizjologii narządów, w wiarygodny sposób odtworzyć poza organizmem. Biorąc pod uwage wspomniane wyżej ograniczenia, możliwość śledzenia losu ludzkich komórek pluripotentnych w chimerach międzygatunkowych, np. ludzko-mysich, stanowi innowacyjne rozwiązanie. Takie podejście badawcze może pomóc w zrozumieniu bardzo wczesnych etapów embriogenezy, np. gastrulacji czy mechanizmów różnicowania komórek progenitorowych specyficznych dla tkanek, których badanie u człowieka nie jest możliwe z powodu braku dostępu do zarodka zagnieżdżonego w macicy. Problem występuje również w przypadku gamet, które można uzyskać in vitro, w wyniku różnicowania komórek iPS. Oocyty wytwarzane z tych pluripotentnych komórek mają ograniczoną zdolność osiągania dojrzałości mejotycznej w hodowli in vitro. Możliwość wytwarzania ludzkich gamet w organizmie zwierząt daje nadzieję na pokonanie tej przeszkody i w efekcie mogłaby dostarczyć nie tylko nowych narzędzi do badań nad rozwojem i dojrzewaniem komórek rozrodczych, ale w przyszłości mogłaby również pomóc pacjentom z azoospermią lub przedwczesną niewydolnością jajników.

Pierwsze próby utworzenia zarodków chimerowych człowieka i myszy poprzez iniekcję ludzkich zarodkowych komórek macierzystych do mysiego zarodka, podjęte w 2006 roku, nie były udane. Komórki ludzkie były w trakcie rozwoju całkowicie eliminowane $\mathrm{z}$ zarodka myszy, prawdopodobnie ze względu na niezgodność ich stopnia rozwoju z zarodkiem biorcy [65]. Wykazano bowiem, że hES reprezentują stadium „primed”, czyli wstępnie ukierunkowane do dalszego różnicowania, podobne do postimplantacyjnego epiblastu, w przeciwieństwie do stadium „naive”, imitującego węzeł zarodkowy, które obserwowane jest w przypadku mysich komórek ES [66]. Dopiero ludzkie komórki pluripotentne, które dzięki zahamowaniu ścieżki mTOR (ang. mammalian Target Of Rapamycin) zostały przekształcone w komórki „naive”, przypominające mysie komórki ES, mogły pomyślnie inkorporować do mysich zarodków. Przeszczepienie tak zmodyfikowanych ludzkich komórek pluripotentnych zaowocowało uzyskaniem 18-dniowych zarodków chimerowych, zawierających nawet do $4 \%$ ludzkich komórek, które różnicowały m.in. w czerwone krwinki [67].

Przed naukowcami jeszcze daleka droga, ale postęp w tego typu badaniach mógłby umożliwić wgląd w skrywane tajemnice ludzkiego rozwoju, a co za tym idzie, pomóc w poznaniu przyczyn bezpłodności czy poronień, do których dochodzi w ciągu pierwszych dni po zapłodnieniu, oraz znalezieniu sposobów jak im zapobiec.

\section{CHIMERY MIEQDZYGATUNKOWE: ŚWIETYY GRAAL WSPÓECZESNEJ TRANSPLANTOLOGII?}

Niepowodzenie badań nad chimerami ludzko-mysimi nie zraziło naukowców, ale zainspirowało ich do podjęcia prób uzyskania chimer międzygatunkowych, w których wybrany narząd budowałyby komórki tylko jednego gatunku. Nie byłoby to możliwe bez nowoczesnych narzędzi do edycji genomu, dzięki którym można zaburzyć w przedimplantacyjnym zarodku program rozwojowy leżący $\mathrm{u}$ podstaw organogenezy. $\mathrm{W}$ tym celu, w pierwszym tego typu doświadczeniu naukowcy zastosowali technologię CRISPR/Cas9, która pozwala na precyzyjną modyfikację genomowego DNA komórek. Za pośrednictwem jednoczesnej iniekcji specyficznej sekwencji sgRNA (ang. single guide RNA) oraz mRNA endonukleazy Cas9 do mysich zygot, unieczynnili w rozwijającym się zarodku Pdx1 (ang. Pancreatic and duodenal homeobox 1), będący kluczowym genem odpowiedzialnym za tworzenie trzustki, w tym komórek $\beta$ produkujących insulinę [68]. Myszy $P d x 1^{\text {- }}$ rodzą się bez trzustki i giną krótko po urodzeniu z powodu braku insuli-

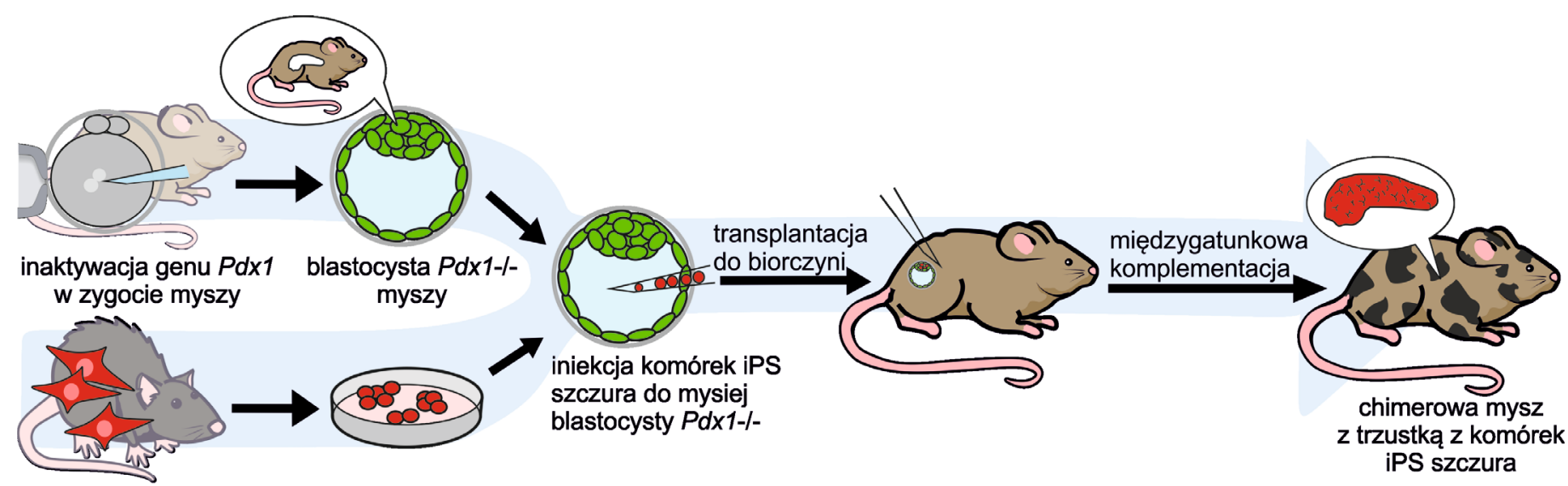

fibroblasty szczura komórki iPS szczura

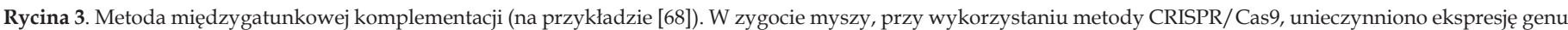

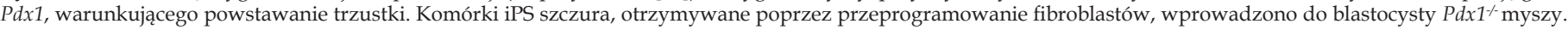

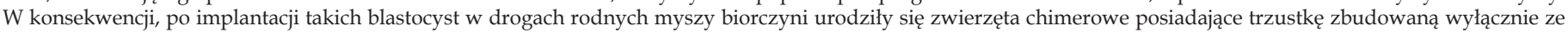
wstrzykiwanych, szczurzych komórek. 
ny. Dzięki specyficznej manipulacji genetycznej naukowcy zdołali zaburzyć przebieg organogenezy, "stwarzając" pustą niszę w rozwijającym się zarodku. Tak zmodyfikowaną genetycznie zygotę hodowali do stadium blastocysty, a następnie do jej jamy wstrzykiwali pluripotentne komórki macierzyste szczura [68] (Ryc. 3). Dzięki tzw. międzygatunkowej komplementacji pluripotentne komórki ES szczura wprowadzone do mysich blastocyst pozbawionych funkcjonalnej kopii genu $P d x 1$ „wypełniły” dostępną niszę w rozwijających się zarodkach-biorcach, biorąc udział w budowie ich trzustki. W konsekwencji, po implantacji takich zarodków w drogach rodnych samicy biorczyni (myszy), urodziły się zwierzęta chimerowe posiadające trzustkę zbudowaną wyłącznie ze wstrzykiwanych, szczurzych komórek [68,69] (Ryc. 3). Warto jednak wspomnieć, że związane $\mathrm{z}$ trzustką naczynia krwionośne, nerwy oraz tkanka łączna były chimerowe, czyli zbudowane z komórek zarówno szczurzych, jak i mysich. Wydajność otrzymywania chimer szczurzo-mysich wyniosła $\mathrm{w}$ tym doświadczeniu $20 \%$, a największy odsetek komórek szczurzych w narządach, poza trzustką, zaobserwowano w sercu (ok. 10\%). Pomimo dość dużego wkładu szczurzych komórek w ciele chimer, ich wielkość, tempo wzrostu oraz rozmiar narządów były determinowane przez mysz, czyli gatunek, z którego wywodziła się blastocysta oraz matka. Chimerowe osobniki szczurzo-mysie były zdrowe, osiągały wielkość charakterystyczną dla myszy i dożywały 2 lat, czyli wieku typowego dla tego gatunku. Ponieważ myszy, w przeciwieństwie do szczurów, posiadają woreczek żółciowy, jego obecność w tak powstałych chimerach wydaje się być również determinowana przez gatunek gospodarza. Oznacza to, że wprowadzone do blastocysty gospodarza komórki pluripotentne podlegają regulacji przez jego program rozwojowy kontrolujący organogenezę.

W podobnym doświadczeniu, w którym wstrzykiwano szczurze komórki ES do blastocyst myszy bezgrasiczych $\mathrm{Nu} / \mathrm{Nu}$, uzyskano chimery mysio-szczurze z grasicą zbudowaną ze szczurzych komórek [70]. W ślad za tymi pracami pojawiła się kolejna, pokazująca, że inaktywując w zarodku biorcy (myszy) geny odpowiedzialne za rozwój konkretnych narządów, np. Nkx2.5 (ang. Nk2 homeobox) dla serca czy Pax6 (ang. Paired box 6) dla oka, można uzyskać chimery, w których te specyficzne narządy będą zbudowane wyłącznie z komórek pochodzących od wstrzykiwanych, szczurzych komórek iPS [69]. Wykazano również, że w przypadku gryzoni, opisana strategia działa $\mathrm{w}$ obie strony [68,71,72]. Jako przykład można przytoczyć pracę, w której wprowadzając mysie komórki pluripotentne do szczurzej blastocysty pozbawionej genu Sall1 (ang. Spalt-like 1), niezbędnego dla morfogenezy nerki, naukowcy dowiedli, że metodą komplementacji blastocysty można uzyskać również chimery posiadające nerki zbudowane $\mathrm{w}$ całości z mysich komórek [71].

Te doświadczenia, w świetle ogromnego deficytu narządów do przeszczepów, rozbudziły wielkie nadzieje na produkcję ludzkich narządów w organizmach zwierząt. Co więcej, tworzone w ten sposób narządy mogłyby być „skrojone na miarę", tzn. w przypadku zastosowania komórek iPS byłyby genetycznie zgodne z pacjentem-biorcą. Dzięki temu zminimalizowane zostałoby ryzyko odrzucenia prze- szczepu czy konieczności stosowania uciążliwej immunosupresji. Ludzkie narządy hodowane $w$ ciałach chimer mogłyby w ten sposób przyczynić się do rozwiązania równocześnie dwóch najważniejszych wyzwań, z którymi boryka się współczesna transplantologia: ograniczonej liczby dostępnych narządów oraz braku zgodności między dawcą i biorcą. Idąc tym tropem dalej, można byłoby genetycznie modyfikować komórki iPS pacjenta przed wprowadzeniem ich do blastocysty i przy pomocy metody edytowania genów CRISPR/Cas9 "naprawiać” defekt w narządzie, który miałby zostać „wyprodukowany”. Byłby to przykład spersonalizowanej medycyny $\mathrm{np}$. dla pacjentów $\mathrm{z}$ wielotorbielowatym zwyrodnieniem nerek, hemochromatozą czy kardiomiopatią.

Naukowcy postanowili zweryfikować przydatność tej strategii, aby opracować zwierzęcy model przeszczepu wysp trzustkowych wyhodowanych $\mathrm{w}$ organizmie chimery. W pierwszej kolejności, metodą komplementacji szczurzej blastocysty, utworzyli chimery posiadające trzustkę zbudowaną z komórek pochodzących w całości z mysich iPS. W kolejnym kroku, z trzustki takiej chimery wyizolowali wysepki trzustkowe, które przeszczepili następnie myszom, u których wcześniej eksperymentalnie, przy pomocy streptozotocyny, zaindukowali cukrzyce [73]. Ze względu na niewielką liczbę komórek szczurzych immunosupresję trzeba było zastosować u myszy tylko przez kilka dni. Wykazano, że komórki endokrynne, zewnątrzwydzielnicze i przewody trzustkowe pochodzily całkowicie z komórek pluripotentnych i były prawidłowe morfologicznie. Co więcej, przeprowadzone testy tolerancji glukozy wykazały, że myszy cierpiące na cukrzycę, którym przeszczepiono wysepki trzustkowe pobrane od chimery, utrzymywały prawidłowy poziom glukozy we krwi przez ponad rok [73]. To doświadczenie dowiodło, że tkanki utworzone z udziałem chimer są funkcjonalne i potencjalnie mogłyby być wykorzystane do leczenia różnych chorób, w tym cukrzycy.

\section{CZŁEKO-ZWIERZ, CZYLI ILE CZŁOWIEKA W ZWIERZECCIU?}

Adaptacja metody, która okazała się skuteczna w przypadku gryzoni, do produkcji ludzkich narządów, wymagałaby wykorzystania jako „inkubatorów” dużych zwierząt np. gospodarskich. Ze względu na podobną do człowieka wielkość, anatomię i fizjologię narządów, szybkość osiągania dojrzałości płciowej, krótką ciążę oraz wielkość miotów, a także względnie niskie koszty utrzymania, wybór padł na świnie i bydło.

Pierwszą próbę uzyskania chimer międzygatunkowych z użyciem ludzkich komórek pluripotentnych i zarodków zwierząt innych niż gryzonie, opisano w 2017 roku na łamach czasopisma Cell [69]. Jako zarodki biorcy zastosowano niemodyfikowane genetycznie blastocysty świńskie i bydlęce, uzyskane odpowiednio na drodze zapłodnienia in vitro i partenogenezy, czyli procesu, w którym zarodek powstaje bezpośrednio ze stymulowanego impulsem elektrycznym oocytu, bez udziału plemnika. Do blastocyst wprowadzono ludzkie iPS, otrzymane poprzez reprogramowanie fibroblastów pochodzących z ludzkiego napletka. Ponieważ wcześniejsze badania sugerowały, że kluczowa dla pomyślnego rozwoju chimer jest synchronizacja stadium 
rozwojowego komórek dawcy z zarodkiem biorcy, zastosowano hiPS, które dzięki specyficznym warunkom hodowli znajdowały się w stadium „naive”, czyli imitującym mysie zarodkowe komórki macierzyste, stadium „primed”, czyli wstępnie ukierunkowanym do dalszego różnicowania oraz w stadium pośrednim. Analiza zarodków chimerowych w stadium przedimplantacyjnym wykazała, że ludzkie komórki z powodzeniem inkorporowały się w ICM blastocyst zarówno świńskich, jak i bydlęcych. Aby sprawdzić, jak będzie przebiegał ich dalszy rozwój po implantacji, część skonstruowanych $\mathrm{w}$ ten sposób blastocyst chimerowych ludzko-świńskich przeszczepiono do biorczyni - lochy, a ciążę utrzymywano przez 3 tygodnie. Rozwój chimer utworzonych przez połączenie bardzo odległych ewolucyjnie gatunków, jakimi dla ludzi są np. świnie (dystans ewolucyjny w ich przypadku wynosi ponad 90 milionów lat), okazał się bardzo ograniczony. Większość prawidłowo rozwijających się płodów nie zawierała komórek ludzkich, a te, które je posiadały, charakteryzowały się opóźnionym rozwojem. Odsetek płodów cechujących się prawidłową morfologią i rozmiarami, zawierających ludzkie komórki, wyniósł około $1 \% \mathrm{w}$ stosunku do liczby wszystkich przeszczepionych blastocyst (17 płodów na 1466 blastocyst). Spośród prawidłowo rozwijających się chimer największy odsetek stanowiły te, do których wprowadzono komórki w stadium pośrednim.

Wydajność tworzenia chimer ludzko-świńskich i ludzko-bydlęcych okazała się znacząco niższa, niż w przypadku gryzoni - myszy i szczura. Zdaniem naukowców, nie bez znaczenia jest tutaj dystans ewolucyjny dzielący obydwa gatunki, który przekłada się na znaczące różnice w przebiegu i tempie ich rozwoju. Stąd narodził się pomysł aby zbadać, czy w przypadku małp, które są dla człowieka bliższe ewolucyjnie, rozwój chimer byłby bardziej pomyślny. $\mathrm{W}$ tym celu, do stworzenia chimer badacze wykorzystali blastocysty makaka krabożernego Macaca fascicularis oraz ludzkie komórki pluripotentne o rozszerzonym potencjale (komórki hEPS, ang. human Extended Pluripotent Stem Cells), mające zdolność do różnicowania nie tylko w tkanki zarodkowe, ale również w struktury pozazarodkowe [74]. Dzięki wyznakowaniu fluorescencyjnemu ludzkich komórek hEPS, badaczom udało się zaobserwować, że z powodzeniem integrowały się one z komórkami blastocysty makaka. Ze względów etycznych zarodki chimerowe nie były transplantowane do biorczyń, ale w zamian za to były utrzymywane w przedłużonej hodowli ex vivo, pozwalającej na obserwację wczesnych etapów postimplantacyjnych i rozwój zarodka aż do etapu gastrulacji. Komórki ludzkie przeżywały i uczestniczyły w rozwoju chimerowego zarodka aż do 19. dnia hodowli, współtworząc wraz z nim tkanki zarodkowe. Mimo znacznej śmiertelności chimerowych zarodków, badacze mieli możliwość prześledzenia molekularnych mechanizmów interakcji między komórkami obu gatunków w obrębie jednego zarodka. Ponadto, posłużyli się metodą sekwencjonowania RNA pojedynczych komórek (scRNA, ang. single cell RNA sequencing) aby zbadać transkryptomy komórek obu gatunków w różnych stadiach rozwojowych. Analiza ta wykazała, że obecność ludzkich komórek w zarodkach małp prowadziła do zmiany ekspresji niektórych genów oraz zwiększenia liczby oddziaływań między ligandami i receptorami. Zdaniem naukowców prowadzi to do aktywacji dodatkowych ścieżek sygnalizacyj- nych, których dalsza analiza może okazać się kluczem do odkrycia, które z tych szlaków są zaangażowane w komunikację między komórkami różnych gatunków [74].

\section{CHIMERY MIEDZYGATUNKOWE JAKO STRATEGIA RATOWANIA GINĄCYCH GATUNKÓW}

Chimery międzygatunkowe wzbudzają również wielkie nadzieje na wykorzystanie ich jako narzędzia do ratowania gatunków zwierząt, którym grozi wyginięcie. Kamieniem milowym w tej dziedzinie było uzyskanie komórek iPS pochodzących od kolcoszczurka amamijskiego - Tokudaia osimensis - małego gryzonia z rodziny myszowatych, zagrożonego wyginięciem $\mathrm{z}$ powodu ograniczonego zasięgu występowania. Komórki iPS tego zamieszkującego jedną z japońskich wysp zwierzęcia, wprowadzono do zarodków myszy, gdzie zasiedlały gonady i różnicowały w gamety [75]. Chociaż wydajność różnicowania komórek iPS w linię płciową w środowisku ksenogenicznym była niewielka, wyniki tych badań pozwoliły na zgłębienie m.in. mechanizmów determinacji płci i genezy gamet. Zainspirowały także naukowców do podjęcia dalszych prac mających na celu wykorzystanie podobnej strategii do zachowania gatunków zagrożonych wyginięciem.

Kolejnym ważnym krokiem w tym kierunku było wprowadzenie mysich komórek ES do blastocyst szczura pozbawionych genu Prdm14 (ang. PR-domain containing protein 14), którego brak uniemożliwił specyfikację szczurzych komórek płciowych. Dzięki temu w rozwijających się chimerach mogły powstać gamety pochodzenia mysiego [76]. Na skutek wprowadzonej mutacji, od 15. dnia rozwoju gonady kolonizowały wyłącznie mysie pierwotne komórki płciowe, a w dorosłych chimerach obecne były trzy jądra, z czego dwa zbudowane wyłącznie z mysich komórek płciowych, zdolnych do przechodzenia prawidłowej spermatogenezy. Powstające $\mathrm{z}$ nich mysie spermatydy charakteryzowały się co prawda zaburzoną ruchliwością, ale były zdolne do zapłodnienia mysich oocytów metodą in vitro i w konsekwencji dawały normalne potomstwo. To doświadczenie dało nadzieję na to, że dzięki komplementacji blastocysty w linii płciowej możliwe będzie wydajne otrzymywanie gamet, a z nich zarodków, które po transplantacji do biorczyni blisko spokrewnionego gatunku, rozwijałyby się $\mathrm{w}$ osobniki należące do gatunków zagrożonych lub wymarłych [76]. Uzyskanie w ostatnim czasie komórek iPS m.in. orangutana [77], nosorożca białego północnego [78] czy pantery śnieżnej [79] świadczy o tym, że perspektywa zastosowania chimer $\mathrm{z}$ ich udziałem do tworzenia funkcjonalnych gamet, a w efekcie do odnowienia populacji tych zagrożonych wyginięciem zwierząt, jest jak najbardziej realna.

\section{ZAGROŻENIA I WYZWANIA}

Obserwacje poczynione przez naukowców wskazują na to, że zanim strategia $\mathrm{z}$ udziałem chimer międzygatunkowych będzie mogła zostać wykorzystana do ratowania ginących gatunków, a tym bardziej do produkcji ludzkich narządów nadających się do transplantacji, naukowcy muszą zmierzyć się z wieloma wyzwaniami natury biologicznej, technicznej i etycznej. 
Po pierwsze, niezbędne wydaje się zdefiniowanie mechanizmów bariery międzygatunkowej, która ogranicza kolonizację zwierzęcych zarodków ludzkimi komórkami. Im większy dystans ewolucyjny między gatunkami tworzącymi chimerę, tym większe bowiem różnice w czasie i przebiegu ich rozwoju. Wiąże się to m.in. $z$ istnieniem odmiennych ścieżek sygnalizacyjnych oraz różnic w powinowactwie białek adhezyjnych, uniemożliwiających prawidłową komunikację między komórkami budującymi obcogatunkowe komponenty. Kluczowa wydaje się także zgodność stadium rozwojowego komórek dawcy z zarodkiem biorcy, jak również zdolność do przeżycia komórek jednego gatunku w środowisku zarodka-gospodarza należącego do innego gatunku. Pierwszą przeszkodę można już pokonać, tak manipulując warunkami hodowli, aby przekształcić ludzkie komórki ES i iPS w komórki o charakterze "naive”. Drugą kwestię również udało się naukowcom rozwiązać. Wykazano, że hamując apoptozę poprzez nadekspresję regulatorów apoptozy, takich jak np. Bcl2 (ang. B-cell lymphoma 2) czy Bmi1 (ang. B lymphoma Mo-MLV insertion region 1 homolog) w szczurzych i ludzkich komórkach można poprawić ich przeżywalność w mysim zarodku, a tym samym zwiększyć stopień chimeryzmu [80-82]. Podobny sukces osiągnięto w przypadku hiPS, które dzięki nadekspresji Bcl2 oraz delecji Tp53 (ang. Tumor protein P53), odpowiedzialnego za apoptozę komórek z uszkodzeniami w obrębie DNA, utrzymywały się w ludzko-świńskich zarodkach nawet do 27. dnia rozwoju [83].

Kolejnym, dużym wyzwaniem dla naukowców będzie takie ukierunkowanie różnicowania pluripotentnych ludzkich komórek macierzystych, aby preferencyjnie zasiedlały "stworzoną" w zarodku gospodarza niszę i tworzyły pożądany narząd, zamiast rozwijać się w inne tkanki. Wbudowanie ludzkich komórek macierzystych do mózgu i linii płciowej stanowi jedną z największych obaw dotyczących tworzenia chimer zwierzęco-ludzkich. Obawa ta nie jest całkowicie bezpodstawna. Biorąc pod uwagę, że jak wykazano, chimery szczurzo-mysie są zdolne do produkcji plemników wywodzących się ze wstrzykniętych pluripotentnych komórek macierzystych [70], można przypuszczać, że chimery zwierzęco-ludzkie również miałyby potencjał do tworzenia ludzkich gamet. Podobne obiekcje i lęk stwarza perspektywa udziału komórek ludzkich w mózgu chimery, co mogłoby wpłynąć na niekontrolowany i nieprzewidywalny wzrost zdolności poznawczych takiego zwierzęcia. W tym przypadku granica definicji człowieka, która do tej pory rozdzielała świat ludzi i zwierząt, mogłaby ulec zatarciu. Jedną ze strategii przeciwdziałającej humanizacji chimer niosących ludzkie narządy byłoby ograniczenie różnicowania komórek pluripotentnych tylko $\mathrm{w}$ pożądanym kierunku. Udało się to już przeprowadzić u myszy, gdzie wymuszona ekspresja Mixl-1 (ang. Mix-like protein 1) umożliwiła udział mysich komórek ES i iPS wyłącznie w narządach pochodzenia endodermalnego [84]. Innym możliwym rozwiązaniem jest wprowadzenie do ludzkich komórek hiPS konstruktów zawierających geny samobójcze pod promotorami specyficznymi dla neuronów lub komórek płciowych tak, by wykluczyć ich udział w korze mózgowej lub linii płciowej
[85]. Jeszcze inną strategię zastosowali japońscy naukowcy, którzy zmodyfikowali ludzkie komórki iPS metodą CRISPR/Cas9, pozbawiając je dwóch genów: Prdm14 (ang. $P R$-domain containing protein 14) odpowiedzialnego za specyfikacje pierwotnych komórek płciowych oraz Otx2 (ang. Orthodenticle Homeobox 2) kluczowego dla rozwoju mózgu. Tak zmodyfikowane komórki dawcy, po wprowadzeniu do blastocyst myszy pozbawionych genu $P d x 1$ nie brały udziału w tworzeniu gamet oraz struktur mózgu, natomiast efektywnie zasiedlały pustą niszę spowodowaną brakiem genu $P d x 1$, tworząc trzustkę i tym samym przyczyniając się do poprawy upośledzonej tolerancji glukozy u chimerowego zwierzęcia [86]. Efektywnym sposobem na ograniczenie udziału komórek ludzkich tylko do docelowego narządu jest także transplantacja specyficznych komórek progenitorowych pochodzących od hiPS do konkretnego narządu postimplantacyjnego płodu rozwijającego się w macicy [35].

Innym problemem, z którym muszą zmierzyć się naukowcy, jest ryzyko odrzucenia przeszczepu. Nawet jeśli udałoby się doprowadzić do narodzin chimery, która posiadałaby narząd z miąższem zbudowanym z ludzkich komórek, to nadal jego unerwienie oraz unaczynienie będzie pochodzenia zwierzęcego. Badacze musieliby znaleźć sposób na to, aby zwiększyć konkurencyjność ludzkich komórek np. w układzie naczyniowym poprzez tworzenie odpowiednich nisz albo zastosować jako biorców podwójne mutanty, pozbawione zdolności do tworzenia konkretnego narządu oraz naczyń krwionośnych. Innym rozwiązaniem są genetyczne modyfikacje genomu zwierząt przewidzianych jako biorcy, np. świni, które mają na celu obniżenie międzygatunkowej bariery immunologicznej pomiędzy tym gatunkiem a człowiekiem. Za nadostre odrzucenie przeszczepu odpowiedzialny jest głównie świński antygen Gala(1,3)Gal, którego biosynteza warunkowana jest przez enzym 1,3-Galaktozylotransferazę. Aby więc umożliwić ksenotransplantację tkanek $\mathrm{w}$ układzie świnia-człowiek naukowcy musieli go usunąć z powierzchni komórek, inaktywując w genomie świni kodujący go gen - Ggta1 (ang. Alpha-1,3-galactosyltransferase 1) lub modyfikując antygeny powierzchniowe świni poprzez uzyskanie ekspresji ludzkiej wersji Gala(1,3)Gal [87].

Inne niebezpieczeństwo, z którym przyjdzie zmagać się naukowcom, to możliwość przeniesienia zwierzęcych patogenów ze zwierząt na człowieka. Dlatego też uważa się, że naczelne, będące nosicielami patogenów, które łatwo infekują ludzi, nie są obiecującymi dawcami narządów do przeszczepów. Z kolei w przypadku świń istnieje ryzyko zakażenia ludzkich tkanek endogennymi retrowirusami, które nie są groźne dla zwierząt, ale ich wpływu na zdrowie człowieka nie da się przewidzieć. Biorąc jednak pod uwagę, że postęp technologii edytowania genów umożliwił już uzyskanie blastocyst świńskich wolnych od endogennych retrowirusów [88], oraz to, że udało się potwierdzić komplementację blastocyst świńskich i owczych pozbawionych zdolności do tworzenia trzustki $[89,90]$ czy mięśni szkieletowych [83], to tylko kwestią czasu wydaje się stworzenie zarodka gospodarza z dodatkową modyfikacją obniżającą barierę immunologiczną, który stałby się złotym standardem dla przyszłych zastosowań klinicznych. 


\section{CHIMERY NA RATUNEK: MODELOWANIE CHORÓB CZŁOWIEKA I ICH TERAPII}

Chimery ludzko-zwierzęce stanowią nie tylko obiecującą strategię pozyskiwania nowych narządów i tkanek dla zaspokojenia coraz większych potrzeb transplantologii, ale są także niezawodnym modelem do badań nad rozwojem narządów, patogenezą, obroną immunologiczną i badaniami przesiewowymi leków.

Rewolucyjne znaczenie dla wykorzystania komórek pluripotentnych w modelowaniu chorób człowieka miało uzyskanie ludzkich komórek iPS oraz pokonanie bariery międzygatunkowej. Ludzkie indukowane komórki pluripotentne można otrzymać od pacjentów cierpiących na różne schorzenia, a jeśli choroba ma podłoże genetyczne, wyhodowane w laboratorium komórki będą miały tę samą wadę genetyczną. $\mathrm{W}$ badaniach in vivo $\mathrm{z}$ użyciem chimer, $\mathrm{w}$ przeciwieństwie do hodowli in vitro, można odtworzyć wiele skomplikowanych interakcji, jakie zachodzą między badanymi komórkami a innymi komórkami i tkankami obecnymi w organizmie podczas rozwoju choroby. Umożliwia to badanie patomechanizmów różnych chorób, a także opracowywanie ich terapii.

Największy postęp w modelowaniu chorób widoczny jest w systemach doświadczalnych, w których komórki pochodzące od hiPS przeszczepia się nie do zarodków przedimplantacyjnych, ale do płodów postimplantacyjnych lub noworodków. W jednym z takich pionierskich eksperymentów naukowcy wprowadzili do mózgów mysich noworodków pochodzące od ludzkich komórek iPS komórki progenitorowe gleju, pełniące w mózgu rolę modulatora. $\mathrm{Ku}$ zaskoczeniu naukowców, komórki ludzkie po pewnym czasie wyparły komórki mysie. Badania behawioralne, testujące pamięć i inne funkcje poznawcze wykazały, że myszy z wprowadzonymi ludzkimi komórkami glejowymi szybciej się uczyły w porównaniu z myszami kontrolnymi. Z kolei gdy przeszczepiono myszom komórki glejowe pochodzące od komórek hiPS pacjentów cierpiących na schizofrenię, zwierzęta wykazywały zwiększony niepokój, zachowania antyspołeczne i zaburzenia snu [91]. W innym eksperymencie naukowcy przeszczepiali ludzkie komórki iPS mysim noworodkom z niedoborami mieliny. Transplantowane komórki różnicowały w oligodendrocyty zdolne do wytwarzania osłonki mielinowej. Naukowcy przecierają $\mathrm{w}$ ten sposób szlaki dla nowych terapii chorób neurologicznych polegających na degeneracji komórek glejowych, do których należą m.in. schizofrenia czy choroba Huntingtona [92].

Obecnie trwa wiele badań klinicznych z wykorzystaniem ludzkich komórek iPS i ES. Przed zatwierdzeniem badań na ludziach konieczne jest ustalenie bezpieczeństwa i skuteczności opracowywanych terapii poprzez dostarczenie obszernych danych przedklinicznych z wykorzystaniem ludzkich pochodnych komórek iPS przeszczepionych do odpowiedniego modelu choroby indukowanego $\mathrm{u}$ zwierząt. Kluczowe wydaje się m.in. potwierdzenie, że testowane komórki nie są zdolne do tworzenia guzów w organizmie gospodarza oraz sprawdzenie, czy integrują się z tkanką gospodarza i przejmują funkcję uszkodzonych komórek.
Jedną z pierwszych chorób poddanych próbom klinicznym było zwyrodnienie plamki żółtej związane z wiekiem (AMD, ang. Age-related Macular Degeneration), charakteryzujące się degeneracją komórek nabłonka barwnikowego siatkówki (RPE, ang. Retinal Pigment Epithelial), będące główną przyczyną ślepoty w krajach rozwiniętych. Wyniki badań z użyciem chimer wskazywały na skuteczne różnicowanie hES w komórki RPE oraz poprawę ostrości wzroku po ich transplantacji do siatkówki szczurów służących jako model tego schorzenia [93,94]. Rezultaty uzyskane na modelu zwierzęcym potwierdziły się następnie w badaniach klinicznych prowadzonych na pacjentach [95].

Inny przykład badań dotyczy urazu rdzenia kręgowego. Doświadczenia poprzedzające badania kliniczne, przeprowadzone na gryzoniach, wykazały, że transplantacja ludzkich komórek ES umożliwia odtworzenie puli oligodendrocytów w uszkodzonym rdzeniu i przyczynia się do przywrócenia funkcji lokomocyjnych u myszy po urazie [96]. W oparciu o wyniki badań na zwierzętach, firma Asterias Biotherapeutics rozpoczęła badania kliniczne z wykorzystaniem komórek prekursorowych oligodendrocytów pochodzących od hES w leczeniu urazów rdzenia kręgowego u ludzi. Dotychczas nie stwierdzono efektów ubocznych związanych z przeszczepem tych komórek, a u części pacjentów rezonans magnetyczny wykazał zmniejszenie obszaru uszkodzenia rdzenia. Następne na horyzoncie mogą być badania kliniczne choroby Parkinsona, neurodegeneracyjnego schorzenia spowodowanego zanikiem komórek produkujących dopaminę. W obszernej literaturze udokumentowano już zdolność ludzkich komórek iPS do tworzenia neuronów dopaminergicznych oraz analizowano wyniki transplantacji tych komórek do mysich modeli choroby Parkinsona [97].

\section{PODSUMOWANIE: NAUKA VS ETYKA}

Nauka przeszła bardzo długą i krętą drogę od przełomowego odkrycia zarodkowych komórek macierzystych, poprzez opracowanie procedur umożliwiających reprogramowanie komórek somatycznych i uzyskanie z nich komórek o właściwościach komórek zarodkowych, aż do tworzenia z ich udziałem chimer. Ogromny postęp oraz udoskonalenie technologii, w tym m.in. odkrycie metody CRISPR/Cas9 do edycji genomu, umożliwiły wykorzystanie modelu, jakim są chimery, do zgłębiania zagadnień mogących nieść za sobą znaczące korzyści nie tylko dla nauki, ale także dla medycyny.

Rozwiązanie problemów technicznych, z którymi borykają się obecnie naukowcy, wydaje się być tylko kwestią czasu, ale trzeba pamiętać, że badania nad chimerami, zwłaszcza ludzko-zwierzęcymi, budzą znaczny opór społeczny i prowadzą do podziałów nawet w środowisku naukowym. Część badaczy podkreśla użyteczność tego typu badań w świetle rozwoju nauki, wierząc, że otworzą one nowy rozdział w historii medycyny, w tym w transplantologii. Z kolei inni mają wątpliwości co do ich bezpieczeństwa i kwestionują potrzebę rozwijania tego kierunku badań, zwłaszcza w kontekście wykorzystania ssaków naczelnych. Zwierzęta te są chronione przez bardziej restrykcyjne przepisy, 
niż np. gryzonie. Zdaniem naukowców, mimo, że chimery powstałe z połączenia ludzkich komórek i komórek innych naczelnych raczej nie znajdą zastosowania w transplantologii, to badania tego typu mogą pomóc w opracowaniu protokołów umożliwiających m.in. wyższą przeżywalność ludzkich komórek w środowisku gospodarza, gdyby jako biorcę zastosowano zamiast naczelnych inne zwierzęta np. gospodarskie [98]. Niezależnie jednak od wytypowanego gatunku gospodarza, w wielu krajach istnieje prawo ograniczające badania nad chimerami stworzonymi z udziałem komórek ludzkich i zwierzęcych. W polskim ustawodawstwie wprowadzono zakaz tworzenia takich międzygatunkowych organizmów na mocy Ustawy o leczeniu niepłodności z 2015 r. (Dz.U. z 2020 r. poz. 442; Art. 86).

Nie bez znaczenia są również głosy obrońców praw zwierząt i przedstawicieli organizacji działających na rzecz poprawy dobrostanu zwierząt hodowlanych, którzy obawiają się, że tego typu badania będą wiązały się z ogromnym cierpieniem zwierząt i ostro protestują przeciwko traktowaniu zwierząt jako żywych magazynów „części zamiennych”. Jeśli nawet realna możliwość wykorzystania chimer do hodowli narządów wydaje się bardzo odległa, to mogą one posłużyć do innych celów, np. zgłębiania wczesnych etapów rozwoju człowieka, wyjaśnienia przyczyn chorób czy badania leków. Ocena takich badań jest jednak trudna i niejednoznaczna. $Z$ jednej strony nowe technologie biomedyczne poszerzają bowiem nasze rozumienie procesów biologicznych, ale z drugiej strony wymagają podjęcia na nowo dyskusji nad granicami ingerencji badaczy w ich przebieg oraz sformułowania nowych norm prawnych i etycznych. Prawdopodobnie już niedługo naukowcy i cała ludzkość stanie w obliczu nowych dylematów natury etycznej związanych $\mathrm{z}$ takimi badaniami.

\section{PIŚMIENNICTWO}

1. Klimczewska K, Kasperczuk A, Suwińska A (2018) Chapter Six - The Regulative Nature of Mammalian Embryos. W: Plusa B, Hadjantonakis A-K (red) Cell Fate Mammalian Development Curr Top Dev Biol. Academic Press, str. 105-149

2. Tarkowski AK (1961) Mouse chimaeras developed from fused eggs. Nature 190: 857-860

3. Mintz B (1962) Experimental Study of the Developing Mammalian Egg: Removal of the Zona Pellucida. Science 138: 594-595

4. Markert CL, Petters RM (1978) Manufactured Hexaparental Mice Show That Adults Are Derived from Three Embryonic Cells. Science 202: 56-58

5. Tang PC, West JD (2000) The effects of embryo stage and cell number on the composition of mouse aggregation chimaeras. Zygote 8: 235243

6. Stevens LC, Varnum DS, Eicher EM (1977) Viable chimaeras produced from normal and parthenogenetic mouse embryos. Nature 269: 515-517

7. Surani MA, Barton SC, Kaufman MH (1977) Development to term of chimaeras between diploid parthenogenetic and fertilised embryos. Nature 270: 601-603

8. Tarkowski AK, Ożdżeński W, Czołowska R (2001) Mouse singletons and twins developed from isolated diploid blastomeres supported with tetraploid blastomeres. Int J Dev Biol 45: 591-596

9. Suwińska A, Ożdżeński W, Waksmundzka M, Tarkowski AK (2005) Experimentally produced diploid<->triploid mouse chimaeras develop up to adulthood. Mol Reprod Dev 72: 362-376

10. Suwińska A, Czołowska R, Ożdżeński W, Tarkowski AK (2008) Blastomeres of the mouse embryo lose totipotency after the fifth cleavage division: Expression of $\mathrm{Cd} x 2$ and Oct4 and developmental potential of inner and outer blastomeres of 16- and 32-cell embryos. Dev Biol 322: 133-144

11. Rossant J, Lis WT (1979) The possible dual origin of the ectoderm of the chorion in the mouse embryo. Dev Biol 70: 249-254

12. Matta CA (1991) Formation by aggregation of viable chimaeras between ICM and eight-cell mouse embryos with different genetic backgrounds. Funct Dev Morphol 1: 35-39

13. Evans MJ, Kaufman MH (1981) Establishment in culture of pluripotential cells from mouse embryos. Nature 292: 154-156

14. Martin GR (1981) Isolation of a pluripotent cell line from early mouse embryos cultured in medium conditioned by teratocarcinoma stem cells. Proc Natl Acad Sci USA 78: 7634-7638

15. Thomson JA, Kalishman J, Golos TG, Durning M, Harris CP, Becker RA, Hearn JP (1995) Isolation of a primate embryonic stem cell line. Proc Natl Acad Sci USA 92: 7844-7848

16. Thomson JA, Kalishman J, Golos TG, Durning M, Harris CP, Hearn JP (1996) Pluripotent cell lines derived from common marmoset (Callithrix jacchus) blastocysts. Biol Reprod 55: 254-259

17. Thomson JA, Itskovitz-Eldor J, Shapiro SS, Waknitz MA, Swiergiel JJ, Marshall VS, Jones JM (1998) Embryonic stem cell lines derived from human blastocysts. Science 282: 1145-1147

18. Shamblott MJ, Axelman J, Wang S, Bugg EM, Littlefield JW, Donovan PJ, Blumenthal PD, Huggins GR, Gearhart JD (1998) Derivation of pluripotent stem cells from cultured human primordial germ cells. Proc Natl Acad Sci USA 95: 13726-13731

19. Buehr M, Meek S, Blair K, Yang J, Ure J, Silva J, McLay R, Hall J, Ying Q-L, Smith A (2008) Capture of Authentic Embryonic Stem Cells from Rat Blastocysts. Cell 135: 1287-1298

20. Li P, Tong C, Mehrian-Shai R, Jia L, Wu N, Yan Y, Maxson RE, Schulze EN, Song H, Hsieh C-L, Pera MF, Ying Q-L (2008) Germline competent embryonic stem cells derived from rat blastocysts. Cell 135: 1299-1310

21. Ueda S, Kawamata M, Teratani T, Shimizu T, Tamai Y, Ogawa H, Hayashi K, Tsuda H, Ochiya T (2008) Establishment of rat embryonic stem cells and making of chimera rats. PLoS One 3: e2800

22. Ying Q-L, Wray J, Nichols J, Batlle-Morera L, Doble B, Woodgett J, Cohen P, Smith A (2008) The ground state of embryonic stem cell self-renewal. Nature 453: 519-523

23. Delhaise F, Bralion V, Schuurbiers N, Dessy F (1996) Establishment of an embryonic stem cell line from blastocyst stage mouse embryos. Eur J Morphol 34: 237-243

24. Chung Y, Klimanskaya I, Becker S, Marh J, Lu SJ, Johnson J, Meisner L, Lanza R (2006) Embryonic and extraembryonic stem cell lines derived from single mouse blastomeres. Nature 439: 216-219

25. Klimanskaya I, Chung Y, Becker S, Lu SJ, Lanza R (2006) Human embryonic stem cell lines derived from single blastomeres. Nature 444: 481-485

26. Al Abbar A, Ngai SC, Nograles N, Alhaji SY, Abdullah S (2020) Induced Pluripotent Stem Cells: Reprogramming Platforms and Applications in Cell Replacement Therapy. Biores Open Access 9: 121-136

27. Takahashi K, Yamanaka S (2006) Induction of pluripotent stem cells from mouse embryonic and adult fibroblast cultures by defined factors. Cell 126: 663-676

28. Takahashi K, Tanabe K, Ohnuki M, Narita M, Ichisaka T, Tomoda K, Yamanaka S (2007) Induction of Pluripotent Stem Cells from Adult Human Fibroblasts by Defined Factors. Cell 131: 861-872

29. Yu J, Vodyanik MA, Smuga-Otto K, Antosiewicz-Bourget J, Frane JL, Tian S, Nie J, Jonsdottir GA, Ruotti V, Stewart R, Slukvin II, Thomson JA (2007) Induced pluripotent stem cell lines derived from human somatic cells. Science 318: 1917-1920

30. Liu G, David BT, Trawczynski M, Fessler RG (2020) Advances in Pluripotent Stem Cells: History, Mechanisms, Technologies, and Applications. Stem Cell Rev Reports 16: 3-32

31. Ciemerych MA (2008) Zarodkowe komórki macierzyste - w poszukiwaniu pluripotencji. Postępy Biol Komórki 35: 183-205 
32. Beddington RS, Robertson EJ (1989) An assessment of the developmental potential of embryonic stem cells in the midgestation mouse embryo. Development 105: 733-737

33. Wang ZQ, Kiefer F, Urbánek P, Wagner EF (1997) Generation of completely embryonic stem cell-derived mutant mice using tetraploid blastocyst injection. Mech Dev 62: 137-145

34. Humięcka M, Krupa M, Guzewska MM, Maleszewski M, Suwińska A (2016) ESCs injected into the 8-cell stage mouse embryo modify pattern of cleavage and cell lineage specification. Mech Dev 141: 40-50

35. Suchy F, Nakauchi H (2018) Interspecies chimeras. Curr Opin Genet Dev 52: 36-41

36. Keighren MA, Flockhart J, Hodson BA, Shen G-Y, Birtley JR, Notarnicola-Harwood A, West JD (2015) Lessons from mouse chimaera experiments with a reiterated transgene marker: revised marker criteria and a review of chimaera markers. Transgenic Res 24: 665-691

37. Smithies O, Gregg RG, Boggs SS, Koralewski MA, Kucherlapati RS (1985) Insertion of DNA sequences into the human chromosomal $\beta$-globin locus by homologous recombination. Nature 317: 230-234

38. Thomas KR, Capecchi MR (1986) Introduction of homologous DNA sequences into mammalian cells induces mutations in the cognate gene. Nature 324: 34-38

39. Austin CP, Battey JF, Bradley A, Bucan M, Capecchi M, Collins FS, Dove WF, Duyk G, Dymecki S, Eppig JT, Grieder FB, Heintz N, Hicks G, Insel TR, Joyner A, Koller BH, Lloyd K, Magnuson T, Moore MW Nagy A, Pollock JD, Roses AD, Sands AT, Seed B, Skarnes WC, Snoddy J, Soriano P, Stewart DJ, Stewart F, Stillman B, Varmus H, Varticovski L, Verma IM, Vogt TF, Von Melchner H, Witkowski J, Woychik RP, Wurst W, Yancopoulos GD, Young SG, Zambrowicz B (2004) The Knockout Mouse Project Europe PMC Funders Group. Nat Genet 36: 921-924

40. Dolgin E (2011) Mouse library set to be knockout. Nature 474: 262-263

41. Adli M (2018) The CRISPR tool kit for genome editing and beyond. Nat Commun 9: 1911

42. Kim H, Kim M, Im S-K, Fang S (2018) Mouse Cre-LoxP system: general principles to determine tissue-specific roles of target genes. Lab Anim Res 34: 147-159

43. Lin S-CJ, Wani MA, Whitsett JA, Wells JM (2010) Klf5 regulates lineage formation in the pre-implantation mouse embryo. Development 137: 3953-3963

44. Beddington RSP, Rashbass P, Wilson V (1992) Brachyury - a gene affecting mouse gastrulation and early organogenesis. Development 116: 157-165

45. Ciruna BG, Schwartz L, Harpal K, Yamaguchi TP, Rossant J (1997) Chimeric analysis of fibroblast growth factor receptor-1(Fgfr1) function: a role for FGFR1 in morphogenetic movement through the primitive streak. Development 124: 2829-2841

46. Hammond V, Howell B, Godinho L, Tan SS (2001) Disabled-1 Functions Cell Autonomously during Radial Migration and Cortical Layering of Pyramidal Neurons. J Neurosci 21: 8798-8808

47. Xu C, Liguori G, Persico MG, Adamson ED (1999) Abrogation of the Cripto gene in mouse leads to failure of postgastrulation morphogenesis and lack of differentiation of cardiomyocytes. Development 126 : 483-494

48. Hanna LA, Foreman RK, Tarasenko IA, Kessler DS, Labosky PA (2002) Requirement for Foxd3 in maintaining pluripotent cells of the early mouse embryo. Genes Dev 16: 2650-2661

49. Huang X, Balmer S, Yang F, Fidalgo M, Li D, Guallar D, Hadjantonakis AK, Wang J (2017) Zfp281 is essential for mouse epiblast maturation through transcriptional and epigenetic control of Nodal signaling. Elife 6: e33333

50. Isermann B, Hendrickson SB, Hutley K, Wing M, Weiler H (2001) Tissue-restricted expression of thrombomodulin in the placenta rescues thrombomodulin-deficient mice from early lethality and reveals a secondary developmental block. Development 128: 827-838

51. Avilion AA, Nicolis SK, Pevny LH, Perez L, Vivian N, Lovell-Badge R (2003) Multipotent cell lineages in early mouse development depend on SOX2 function. Genes Dev 17: 126-140
52. Morrisey EE, Tang Z, Sigrist K, Lu MM, Jiang F, Ip HS, Parmacek MS (1998) GATA6 regulates HNF4 and is required for differentiation of visceral endoderm in the mouse embryo. Genes Dev 12: 3579-3590

53. Shirane M, Sawa H, Kobayashi Y, Nakano T, Kitajima K, Shinkai Y, Nagashima K, Negishi I (2001) Deficiency of phospholipase C-ץ1 impairs renal development and hematopoiesis. Development 128: 5173 5180

54. Nottoli T, Hagopian-Donaldson S, Zhang J, Perkins A, Williams T (1998) AP-2-null cells disrupt morphogenesis of the eye, face, and limbs in chimeric mice. Proc Natl Acad Sci USA 95: 13714-13719

55. Tremblay KD, Dunn NR, Robertson EJ (2001) Mouse embryos lacking Smad1 signals display defects in extra-embryonic tissues and germ cell formation. Development 128: 3609-3621

56. Dragatsis I, Efstratiadis A, Zeitlin S (1998) Mouse mutant embryos lacking huntingtin are rescued from lethality by wild-type extraembryonic tissues. Development 125: 1529-1539

57. Wu J, Greely HT, Jaenisch R, Nakauchi H, Rossant J, Belmonte JCI (2016) Stem cells and interspecies chimaeras. Nature 540: 51-59

58. Bożyk K, Gilecka K, Humięcka M, Szpila M, Suwińska A, Tarkowski AK (2017) Mouse $\leftrightarrow$ rat aggregation chimaeras can develop to adulthood. Dev Biol 427: 106-120

59. Xiang AP, Mao FF, Li W-Q, Park D, Ma B-F, Wang T, Vallender TW, Vallender EJ, Zhang L, Lee J, Waters JA, Zhang X-M, Yu X-B, Li S-N, Lahn BT (2008) Extensive contribution of embryonic stem cells to the development of an evolutionarily divergent host. Hum Mol Genet 17: 27-37

60. Rossant J, Tam PPL (2017) New Insights into Early Human Development: Lessons for Stem Cell Derivation and Differentiation. Cell Stem Cell 20: 18-28

61. Deglincerti A, Croft GF, Pietila LN, Zernicka-Goetz M, Siggia ED, Brivanlou AH (2016) Self-organization of the in vitro attached human embryo. Nature 533: 251-254

62. Shahbazi MN, Jedrusik A, Vuoristo S, Recher G, Hupalowska A, Bolton V, Fogarty NNM, Campbell A, Devito L, Ilic D, Khalaf Y, Niakan KK, Fishel S, Zernicka-Goetz M (2016) Self-organization of the human embryo in the absence of maternal tissues. Nat Cell Biol 18: 700-708

63. Sozen B, Amadei G, Cox A, Wang R, Na E, Czukiewska S, Chappell L, Voet T, Michel G, Jing N, Glover DM, Zernicka-Goetz M (2018) Self-assembly of embryonic and two extra-embryonic stem cell types into gastrulating embryo-like structures. Nat Cell Biol 20: 979-989

64. Fu J, Warmflash A, Lutolf MP (2021) Stem-cell-based embryo models for fundamental research and translation. Nat Mater 20: 132-144

65. James D, Noggle SA, Swigut T, Brivanlou AH (2006) Contribution of human embryonic stem cells to mouse blastocysts. Dev Biol 295: 90-102

66. Morgani S, Nichols J, Hadjantonakis A-K (2017) The many faces of Pluripotency: in vitro adaptations of a continuum of in vivo states. BMC Dev Biol 17: 7

67. Hu Z, Li H, Jiang H, Ren Y, Yu X, Qiu J, Stablewski AB, Zhang B, Buck MJ, Feng J (2020) Transient inhibition of mTOR in human pluripotent stem cells enables robust formation of mouse-human chimeric embryos. Sci Adv 6: eaaz0298

68. Kobayashi T, Yamaguchi T, Hamanaka S, Kato-Itoh M, Yamazaki Y, Ibata M, Sato H, Lee YS, Usui J ichi, Knisely AS, Hirabayashi M, Nakauchi H (2010) Generation of Rat Pancreas in Mouse by Interspecific Blastocyst Injection of Pluripotent Stem Cells. Cell 142: 787-799

69. Wu J, Platero-Luengo A, Sakurai M, Sugawara A, Gil MA, Yamauchi T, Suzuki K, Bogliotti YS, Cuello C, Morales Valencia M, Okumura D, Luo J, Vilariño M, Parrilla I, Soto DA, Martinez CA, Hishida T, Sánchez-Bautista S, Martinez-Martinez ML, Wang H, Nohalez A, Aizawa E, Martinez-Redondo P, Ocampo A, Reddy P, Roca J, Maga EA, Esteban CR, Berggren WT, Nuñez Delicado E, Lajara J, Guillen I, Guillen P, Campistol JM, Martinez EA, Ross PJ, Izpisua Belmonte JC (2017) Interspecies Chimerism with Mammalian Pluripotent Stem Cells. Cell 168: 473-486.e15

70. Isotani A, Hatayama H, Kaseda K, Ikawa M, Okabe M (2011) Formation of a thymus from rat ES cells in xenogeneic nude mouse $\leftrightarrow$ rat ES chimeras. Genes to Cells 16: 397-405 
71. Goto T, Hara H, Sanbo M, Masaki H, Sato H, Yamaguchi T, Hochi S, Kobayashi T, Nakauchi H, Hirabayashi M (2019) Generation of pluripotent stem cell-derived mouse kidneys in Sall1-targeted anephric rats. Nat Commun 10: 451

72. Zheng C, Ballard EB, Wu J (2021) The road to generating transplantable organs: from blastocyst complementation to interspecies chimeras. Development 148: dev195792

73. Yamaguchi T, Sato H, Kato-Itoh M, Goto T, Hara H, Sanbo M, Mizuno N, Kobayashi T, Yanagida A, Umino A, Ota Y, Hamanaka S, Masaki H, Rashid ST, Hirabayashi M, Nakauchi H (2017) Interspecies organogenesis generates autologous functional islets. Nature 542: 191-196

74. Tan T, Wu J, Si C, Dai S, Zhang Y, Sun N, Zhang E, Shao H, Si W, Yang P, Wang H, Chen Z, Zhu R, Kang Y, Hernandez-Benitez R, Martinez Martinez L, Nuñez Delicado E, Berggren WT, Schwarz M, Ai Z, Li T, Rodriguez Esteban C, Ji W, Niu Y, Izpisua Belmonte JC (2021) Chimeric contribution of human extended pluripotent stem cells to monkey embryos ex vivo. Cell 184: 2020-2032.e14

75. Honda A, Choijookhuu N, Izu H, Kawano Y, Inokuchi M, Honsho K, Lee A-R, Nabekura H, Ohta H, Tsukiyama T, Ohinata Y, Kuroiwa A, Hishikawa Y, Saitou M, Jogahara T, Koshimoto C (2017) Flexible adaptation of male germ cells from female iPSCs of endangered Tokudaia osimensis. Sci Adv 3: e1602179

76. Kobayashi T, Goto T, Oikawa M, Sanbo M, Yoshida F, Terada R, Niizeki N, Kajitani N, Kazuki K, Kazuki Y, Hochi S, Nakauchi H, Surani MA, Hirabayashi M (2021) Blastocyst complementation using Prdm14-deficient rats enables efficient germline transmission and generation of functional mouse spermatids in rats. Nat Commun 12: 1-10

77. Ramaswamy K, Yik WY, Wang XM, Oliphant EN, Lu W, Shibata D, Ryder OA, Hacia JG (2015) Derivation of induced pluripotent stem cells from orangutan skin fibroblasts. BMC Res Notes 8: 577

78. Korody ML, Ford SM, Nguyen TD, Pivaroff CG, Valiente-Alandi I, Peterson SE, Ryder OA, Loring JF (2021) Rewinding Extinction in the Northern White Rhinoceros: Genetically Diverse Induced Pluripotent Stem Cell Bank for Genetic Rescue. Stem Cells Dev 30: 177-189

79. Verma R, Holland MK, Temple-Smith P, Verma PJ (2012) Inducing pluripotency in somatic cells from the snow leopard (Panthera uncia), an endangered felid. Theriogenology 77: 220-228

80. Masaki H, Kato-Itoh M, Takahashi Y, Umino A, Sato H, Ito K, Yanagida A, Nishimura T, Yamaguchi T, Hirabayashi M, Era T, Loh KM, Wu SM, Weissman IL, Nakauchi H (2016) Inhibition of Apoptosis Overcomes Stage-Related Compatibility Barriers to Chimera Formation in Mouse Embryos. Cell Stem Cell 19: 587-592

81. Huang K, Zhu Y, Ma Y, Zhao B, Fan N, Li Y, Song H, Chu S, Ouyang Z, Zhang Q, Xing Q, Lai C, Li N, Zhang T, Gu J, Kang B, Shan Y, Lai K, Huang W, Mai Y, Wang Q, Li J, Lin A, Zhang Y, Zhong X, Liao B, Lai L, Chen J, Pei D, Pan G (2018) BMI1 enables interspecies chimerism with human pluripotent stem cells. Nat Commun 9: 4649

82. Wang X, Li T, Cui T, Yu D, Liu C, Jiang L, Feng G, Wang L, Fu R, Zhang X, Hao J, Wang Y, Wang L, Zhou Q, Li W, Hu B (2018) Human embryonic stem cells contribute to embryonic and extraembryonic lineages in mouse embryos upon inhibition of apoptosis. Cell Res 28: 126-129

83. Maeng G, Das S, Greising SM, Gong W, Singh BN, Kren S, Mickelson D, Skie E, Gafni O, Sorensen JR, Weaver C V, Garry DJ, Garry MG (2021) Humanized skeletal muscle in MYF5/MYOD/MYF6-null pig embryos. Nat Biomed Eng 5: 805-814

84. Kobayashi T, Kato-Itoh M, Nakauchi H (2015) Targeted Organ Generation Using Mixl1-inducible Mouse Pluripotent Stem Cells in Blastocyst Complementation. Stem Cells Dev 24: 182-189

85. Rashid T, Kobayashi T, Nakauchi H (2014) Revisiting the Flight of Icarus: Making Human Organs from PSCs with Large Animal Chimeras. Cell Stem Cell 15: 406-409
86. Hashimoto H, Eto T, Yamamoto M, Yagoto M, Goto M, Kagawa T, Kojima K, Kawai K, Akimoto T, Takahashi RI (2019) Development of blastocyst complementation technology without contributions to gametes and the brain. Exp Anim 68: 361-370

87. Tanihara F, Hirata M, Nguyen NT, Sawamoto O, Kikuchi T, Doi M, Otoi T (2020) Efficient generation of GGTA1-deficient pigs by electroporation of the CRISPR/Cas9 system into in vitro-fertilized zygotes. BMC Biotechnol 20: 40

88. Yang L, Güell M, Niu D, George H, Lesha E, Grishin D, Aach J, Shrock E, Xu W, Poci J, Cortazio R, Wilkinson RA, Fishman JA, Church G (2015) Genome-wide inactivation of porcine endogenous retroviruses (PERVs). Science 350: 1101-1104

89. Wu J, Vilarino M, Suzuki K, Okamura D, Bogliotti YS, Park I, Rowe J, McNabb B, Ross PJ, Belmonte JCI (2017) CRISPR-Cas9 mediated onestep disabling of pancreatogenesis in pigs. Sci Rep 7: 10487

90. Vilarino M, Rashid ST, Suchy FP, McNabb BR, van der Meulen T, Fine EJ, Ahsan SD, Mursaliyev N, Sebastiano V, Diab SS, Huising MO, Nakauchi H, Ross PJ (2017) CRISPR/Cas9 microinjection in oocytes disables pancreas development in sheep. Sci Rep 7: 17472

91. Windrem MS, Osipovitch M, Liu Z, Bates J, Chandler-Militello D, Zou L, Munir J, Schanz S, McCoy K, Miller RH, Wang S, Nedergaard M, Findling RL, Tesar PJ, Goldman SA (2017) Human iPSC Glial Mouse Chimeras Reveal Glial Contributions to Schizophrenia. Cell Stem Cell 21: 195-208.e6

92. Benraiss A, Wang S, Herrlinger S, Li X, Chandler-Militello D, Mauceri J, Burm HB, Toner M, Osipovitch M, Jim Xu Q, Ding F, Wang F, Kang N, Kang J, Curtin PC, Brunner D, Windrem MS, Munoz-Sanjuan I, Nedergaard M, Goldman SA (2016) Human glia can both induce and rescue aspects of disease phenotype in Huntington disease. Nat Commun 7: 11758

93. Lund RD, Wang S, Klimanskaya I, Holmes T, Ramos-Kelsey R, Lu B, Girman S, Bischoff N, Sauvé Y, Lanza R (2006) Human embryonic stem cell-derived cells rescue visual function in dystrophic RCS rats. Cloning Stem Cells 8: 189-199

94. Idelson M, Alper R, Obolensky A, Ben-Shushan E, Hemo I, Yachimovich-Cohen N, Khaner H, Smith Y, Wiser O, Gropp M, Cohen MA Even-Ram S, Berman-Zaken Y, Matzrafi L, Rechavi G, Banin E, Reubinoff B (2009) Directed Differentiation of Human Embryonic Stem Cells into Functional Retinal Pigment Epithelium Cells. Cell Stem Cell 5: 396-408

95. Schwartz SD, Regillo CD, Lam BL, Eliott D, Rosenfeld PJ, Gregori NZ, Hubschman J-P, Davis JL, Heilwell G, Spirn M, Maguire J, Gay R, Bateman J, Ostrick RM, Morris D, Vincent M, Anglade E, Del Priore L V, Lanza R (2015) Human embryonic stem cell-derived retinal pigment epithelium in patients with age-related macular degeneration and Stargardt's macular dystrophy: follow-up of two open-label phase 1/2 studies. Lancet 385: 509-516

96. Priest CA, Manley NC, Denham J, Wirth ED, Lebkowski JS (2015) Preclinical safety of human embryonic stem cell-derived oligodendrocyte progenitors supporting clinical trials in spinal cord injury. Regen Med 10: 939-958

97. Steinbeck JA, Choi SJ, Mrejeru A, Ganat Y, Deisseroth K, Sulzer D, Mosharov E V, Studer L (2015) Optogenetics enables functional analysis of human embryonic stem cell-derived grafts in a Parkinson's disease model. Nat Biotechnol 33: 204-209

98. De Los Angeles A, Hyun I, Latham SR, Elsworth JD, Redmond DE (2018) Human-Monkey Chimeras for Modeling Human Disease: Opportunities and Challenges. Stem Cells Dev 27: 1599-1604 


\title{
Chimaeras with the contribution of the pluripotent stem cells as a tool in biomedical research
}

\author{
Eliza Winek, Aneta Suwińska ${ }^{\bowtie}$
}

Department of Embryology, Institute of Developmental Biology and Biomedical Sciences, Faculty of Biology, University of Warsaw

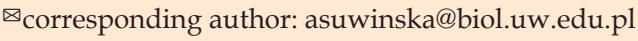

Key words: chimaera, pluripotent cells, embryo, blastocyst complementation, transplantology, ethics

\section{ABSTRACT}

The CHIMAERA has been known as a mythic, fire-breathing monster containing a lion's head, goat's body, and serpent's tail. In modern biotechnology, this term has been used to describe organisms composed of cells derived from at least two zygotes and thus differing genetically. Experimentally produced chimaeras have become an extremely valuable tool in biomedical research, used, among others, for investigating the developmental potential of cells, the differentiation processes that occur during embryogenesis, as well as for studying gene function, modelling human diseases, and developing new therapies. The interspecific chimaeras are also a promising approach for the generation of human organs for transplantation and saving endangered species. This article summarizes the current state of knowledge on chimaeras formed with the contribution of pluripotent stem cells and discusses the prospects and threats related to their use in basic research and medicine.

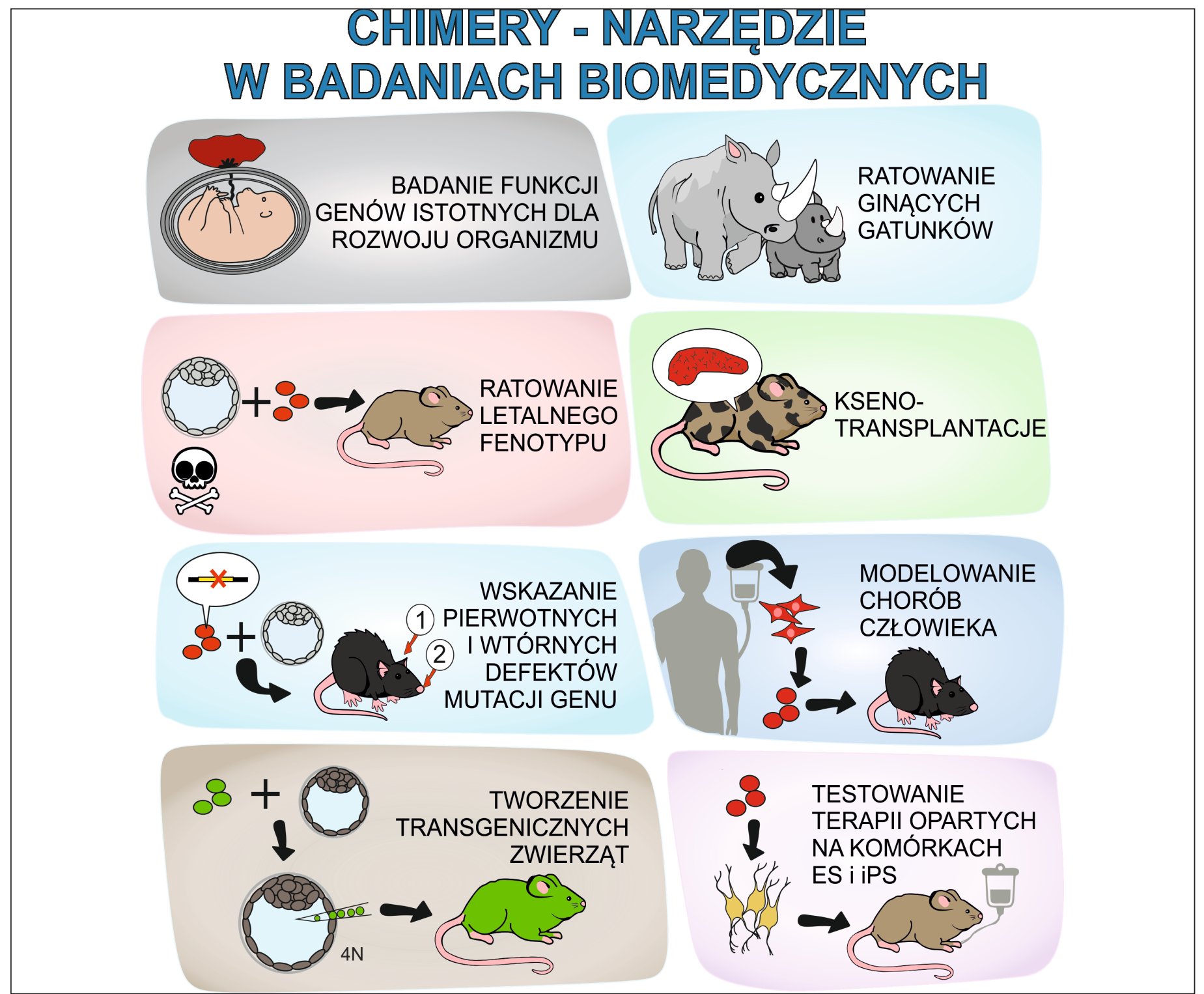

